\title{
9
}

\section{Detouring Kwajalein: At Home Between Coral and Concrete in the Marshall Islands}

\author{
Greg Dvorak
}

\section{Kwaj Kid ${ }^{1}$}

Not too many people know about Kwajalein, a small island in the Marshall Islands. Of course I do, or I wouldn't be writing this essay. The reason I know about it is because I lived there until I was nine years old. When we moved from our home in New Jersey, our predictions were to stay for a year ... then it became another, then another, and finally almost seven years.
14 Here I am in sixth grade in 1984 trying to make sense out of myself and my situation: a little 11-year-old boy sitting at his desk in New Jersey, enduring the third winter ever of his life, up past his bedtime, doing English homework at the last minute - dreaming of sunshine while writing his very first essay about the island home he once took for granted. It has been nearly two years since he moved away from Kwajalein in the Marshall Islands with his family, and the initial chaos has past. In the rapid and turbulent transition from small island tropics to landlocked autumn, the boy believes he has learned to put it all in perspective. He has learned three lessons:

1 I use this two-column style with homage to Teresia Teaiwa, who used a similar layout to narrate her academic and personal journey, and the history of Native Pacific Studies, in her article 'L(o)osing the Edge', The Contemporary Pacific 13(2) (2001): 343-57. Here, I use this format to narrate my own ambivalence about my personal relationship to occupied Marshallese land as 'home'. 
What many people think about Kwaj besides, 'What's that?' usually sounds like this: 'It's too small.' Everyone says that. I think, no, it's not, because in my view it was a little paradise to me. Since it is a missile range, everyone imagines a barren battlefield with a runway and rocket smoke in the air. No way, it's a beautiful, one-square-mile island with palm trees and hibiscus flowers everywhere!

I really should start telling about Kwajalein itself. Homes were supplied by the Army and electricity, phone calls, and water were all free. Homes consisted of trailers and houses. Trailers were nice little homes that most people were used to living in. No, they weren't trailers like you see travelling on the highway, they weren't even like our school's trailers. These were big, well-built, silver trailers! One slight problem we had were cockroaches, big brown cockroaches.

The transportation of Kwaj is an interesting topic. Everyone rode on bikes! Everything was so close to our homes, all you had to do was hop on a bike and ride for two minutes at the most!

One of the most fascinating topics of Kwaj is the ocean. It was very beautiful. Our trailer was located right next to it, so the view out of our dining room window was remarkable. The activities we did were swimming, snorkelling, scuba diving and fishing. Let's not forget sailboating and other numerous activities.
Kwaj is very far away, Kwaj is in the middle of nowhere, and Kwaj is virtually everything New Jersey isn't-sort of. With the exception of the rows and rows of tidy houses, the gated community-feel, the American faces, American food, and Sesame Street, Kwaj might as well be in a completely different universe altogether.

Though he proclaims to know the legend of how 'we' moved to Kwajalein and stayed for seven years, he actually has no recollection of what came before that, or even why we lived there. Nor does he relate to the nostalgia of cold autumn nights and spiced apple cider. But his parents do, and he has begun to cultivate these memories and this identity for his own survival and comfort. For the boy, there actually was never anything but Kwajalein, except for brief summertime sojourns with relatives 'backinthestates'. Backinthestates: the word used to describe the world where Grandmom lived - an alternative reality reached only through a series of flights on trans-Pacific and trans-continental airships.

Physically living backinthestates, however, is another matter: In this other dimension, one must pretend to belong and know, and being as 'grown-up' as he is, the boy has finally begun to learn the ropes. It is a process of putting things in context, framing them like a Waikiki postcard so that everyone understands, making up stories about fishing and surfing for good measure.

After all, 'Kwaj' is in the past. It was temporary. It was just a decade-long vacation in the tropics. It was never really home, he discovers; the biggest joke of his life, like Dorothy waking up from her crazy dreams of $\mathrm{Oz}$ - there's no place like home. And home isn't in the Marshall Islands. Is it? We're Americans, anyway. All just a dream, just a paradise island, just a moment frozen in time, in between Reality and Reality. There are no palm trees in Reality. No baby coconuts to take to the Marshallese maintenance man at the pool for him to custom spraypaint in bright colours. Yes, just a dream, just a place to be. Sort of. 
Even though I didn't fish much, fishing was interesting to watch. Deep sea fishing was most popular. People would go out on boats and ride for hours. Of all the little sailboats that a few people rode on, there was one big grey fishing boat. Today I like to refer to this boat as the big diesel. First of all, it was very huge. Second of all, it was very nauseating and it rocked rapidly. Some fish we caught were mahimahi, a very rich and juicy fish, tuna, flounder, and sunfish.

The people that lived on Kwaj were mostly people from all over the world, usually from the United States. There were also the original inhabitants, the Marshallese. During World War II, they were sort of forced off the island. A few of them even had radiation. After that, they moved out of Kwaj and made their home on an island north of Kwaj called Ebeye.

So all together Kwajalein in the Marshall Islands was and still is a really nice place to live.
And what of 'the Marshallese' who were 'sort of forced' off their islands? What really happened to them, he wonders. Why was Kwaj for Americans, and Ebeye for Marshallese? They smiled and sang and 'had radiation', whatever that meant. All he knew was that Ebeye, a few islands down the chain, was a hideous and fantastic place-it haunted and excited him all at once. It was a treeless place that smelled at once of seafood and fried chicken and sewage and burning trash and birthday cake, and his mother warned him not to touch the broken glass. But it was also the place where children ran freely and laughed, a place of wondrous freedom and camaraderie, where the music blasted and everyone played ball games in the street.

If Kwaj wasn't really home, what, then, is that cozy feeling he remembers of coming back to Kwaj after a long month of summer vacation on the mainland - that snuggly sensation on the way back from the air terminal at night? Soothed by the silent warmth of the island, by the trade winds and the thick smell of flowers and reef barnacles sweating in the damp air, he remembers a sleepy calm as comforting as getting tucked into bed at night, and secretly wishes that he could just go home.

Kwajalein in the Marshall Islands: Almost the first decade of my life. A perfect lagoon to rival the greatest tropical paradises of the world. A testing ground where unarmed missiles fell from the sky. Stolen Marshallese land? Rented Marshallese land? A Really Nice Place to Live. 


\section{Crossings}

It is with this childhood essay ${ }^{2}$ that I welcome you to Kwajalein Atoll in the Marshall Islands, one of the largest inhabited atolls on earth, a vast boomerang-shaped string of roughly 100 slender coral islands encompassing a lagoon of over 2,000 square kilometres. It is a place that has been significant to Islander voyagers and settlers for thousands of years, and also to the Spanish, German, Japanese, and especially American colonial and military communities who claimed or used it over the past centuries to the present.

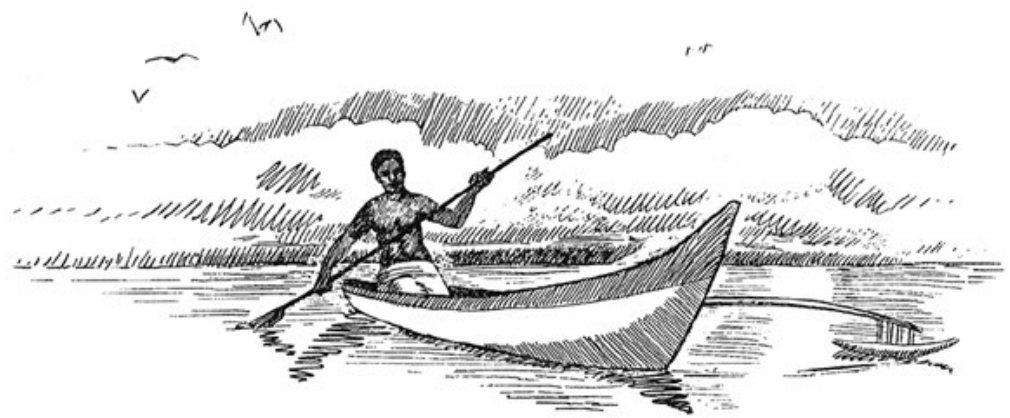

\section{Welcome to Kwajalein}

Figure 32. Cover image from the orientation materials my parents received in 1975.

Source. Bell Laboratories, 1972, 'Kwajalein Orientation Guide', Pamphlet.

History at Kwajalein, as with most Pacific places, is like its reefs, the stories of countless human beings amalgamated like the layers of coral whose tiny polyps migrated from afar, settled, sedimented, and spread further in all directions and dimensions over tens of thousands of years in deep time. Pacific histories, as so many navigators, elders, scholars and artists tell us, are genealogies that connect people

2 For an earlier version of this essay and its interpretation, see my master's thesis, where my focus was on exploring American notions of 'home'. See Greg Dvorak, 2004, 'Remapping home: Touring the betweenness of Kwajalein', MA thesis, University of Hawai'i at Mānoa, Honolulu, 2004. This chapter also draws extensively on my doctoral work about competing Marshallese, Japanese, and American histories at Kwajalein Atoll over the past century. Greg Dvorak, 2008, 'Seeds from afar, flowers from the reef, re-membering the coral and concrete of Kwajalein Atoll', PhD thesis, The Australian National University, Canberra. 
across and through the ocean. They are often contradictory linkages, fraught with pleasure and peril, memory and forgetting, pain and perseverance, and legacies of injustice.

In summer of 1975, not long after the fall of Saigon, a young and eager couple shipped their belongings to the Central Pacific and moved from New Jersey with their baby son to Kwajalein Atoll. My father, a civilian systems engineer at a major aerospace defence company, was invited on a family contract to work in the north of the atoll at the radar installations on Roi-Namur as part of the intercontinental ballistic missile Cold War target practice that was being conducted at the time by the US military. ${ }^{3}$ Commuting daily by small aircraft, he would cross the giant atoll each morning and evening while my mother and I (and later my brother) would spend our days going to school, working, and playing in an idyllic small-town community that looked somewhat like 1950s American suburbia, enhanced by its brilliant turquoise lagoon, coconut palms and tropical flowers. Relocating to 'Kwaj' was, for my parents, a short opportunity to live on a Pacific island for a few years, experience a new environment, have their second child and save money. For me, it was the foundation of my life, the beginning of my own awkward and ambivalent link to a particular Pacific genealogy of war and settlement, when I formed my roots in the reef of that immense and mysterious lagoon.

My family's heritage was, in fact, already comprised of many transoceanic crossings before we crossed the Pacific to the Marshall Islands. My mother's grandmother was still a baby at the turn of the twentieth century when her Jewish family made their Atlantic crossing from Galatz, Romania, to Philadelphia. The man she would marry came from a Roman Catholic family that had crossed a generation earlier from the Abruzzo region of Italy. My mother's paternal grandparents had crossed from the borderlands of Russia and Poland. My father's

3 This 'target practice' continues today, though far more sporadically, having evolved into Ronald Reagan's Strategic Defense Initiative 'Star Wars' programs in the 1980s and later variations that tested the interception of incoming missiles before they impacted earth. In recent decades, the testing site at US Army Garrison Kwajalein Atoll (USAGKA), facilitated by the United States Army but managed by a consortium of corporations, is a location for NASA and private spaceflight testing such as Elon Musk's SpaceX Program, along with a number of other research and space surveillance programs. 
grandfather was a Czech tailor in Manhattan; his grandmother, a brave woman who was only 16 when she crossed from Bratislava seeking her brother who had made his own crossing to find work in the United States. These crossings were plagued with the seasickness of culture shock and the turbulence of change.

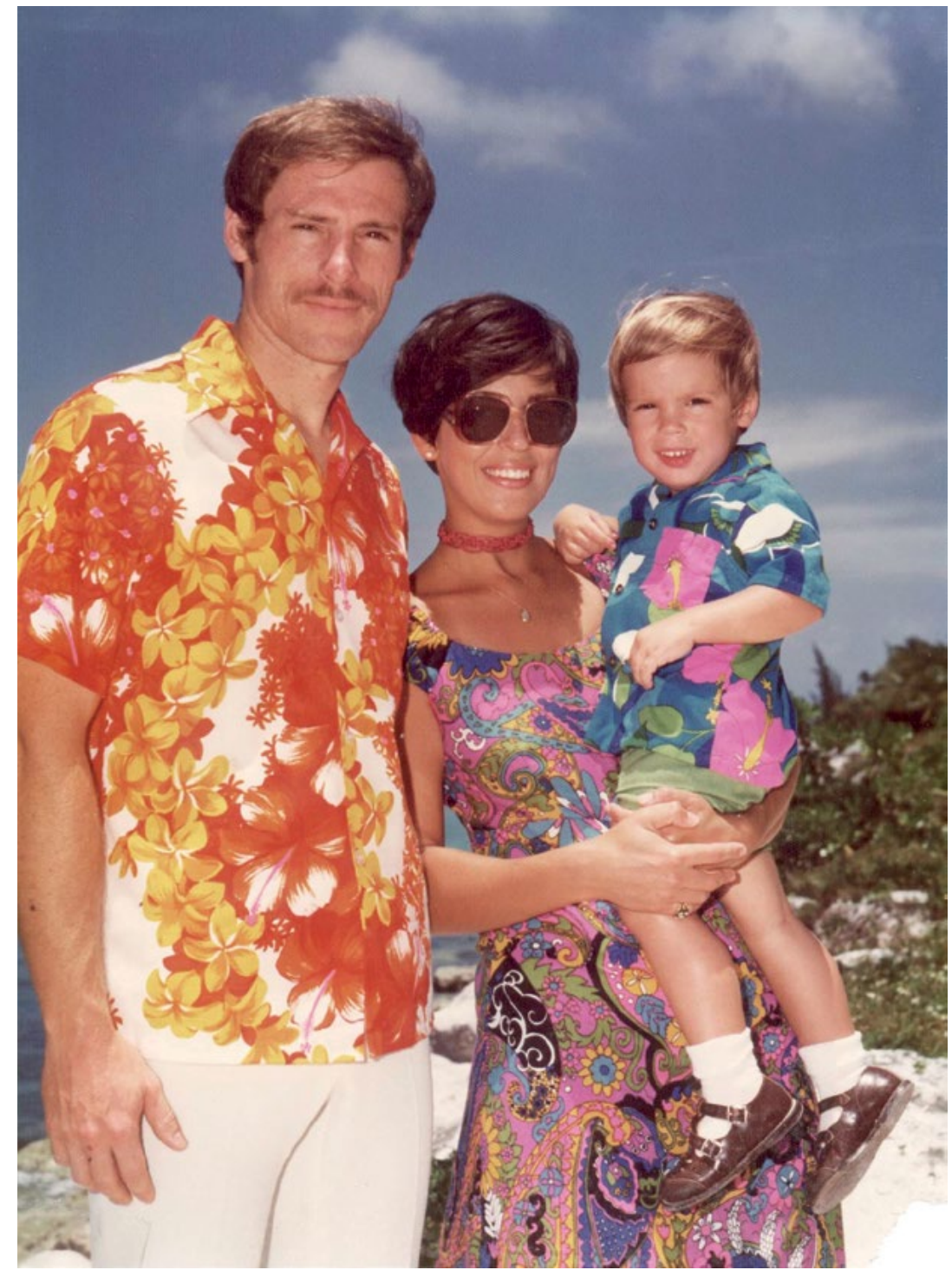

Figure 33. With my father and mother on Kwajalein, 1976.

Source. Family archive, photographer unknown. 


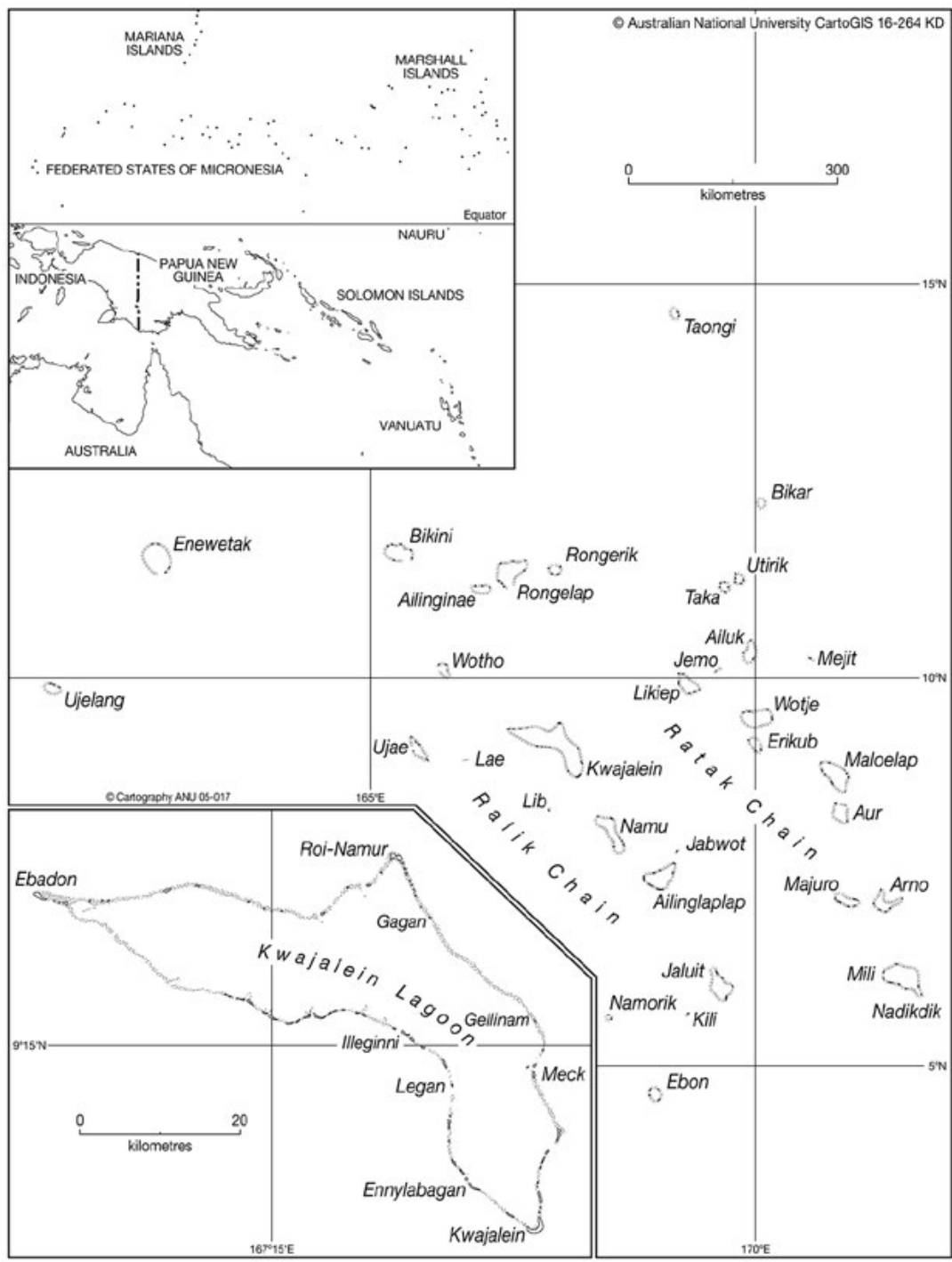

Map 1. Kwajalein Atoll. Kwajalein is the southernmost islet of Kwajalein Atoll, shown here in the lower-left inset.

Source. (C) Australian National University Cartography, CartoGIS 16264 KD. Used with permission.

When my parents carried that hard-to-pronounce Czech name further across another ocean, however, the American mission of national security facilitated and smoothed their sailing. It was a job, a 'tour of duty', and little else. This coaxed them and other American families 
into an ambivalent ignorance about the peacelessness of the Pacific world they entered and the tremendous changes that were taking place throughout Oceania. The year 1975 was one in which 5,000 Māori marched to fight for their land claims in Aotearoa-New Zealand, and when East Timor declared its independence. American history classes and newspapers had not taught my parents the horrific histories of nuclear weapons testing and displacement that Marshall Islanders had already endured for so many decades. They had no idea about the frustration of Kwajalein landowners or their desire to reoccupy the islands Japan and then the United States military had forcefully taken from them-including the land where our American suburbia was located. And they did not realise that even 30 years after the Pacific War had ended, the remains of over 8,000 Japanese and Koreans who died in the Pacific War were still buried beneath the concrete and asphalt where we lived, or that the bereaved family members of those war dead had still not received permission to visit the graves of their loved ones.

\section{Only a tour}

To this day, employees and their families on the Kwajalein base (a group that increasingly includes a small number of Marshallese residents who have higher status jobs on the base) live in a residential zone that was fashioned after a middle-class American community of yesteryear; it was deliberately designed to evoke home-away-from-home and to reassure its constituents that they had never actually left the United States. As historian Lauren Hirshberg writes, 'During the 1960s, the army transformed this Marshallese island into small-town suburban America. Army officials designed Kwajalein as a space that captured one paradoxical narrative of 1950s Cold War America: anxiety over nuclear insecurity eased by the illusion of greater nuclear-family security through the suburban refuge. ${ }^{\prime 4}$

My family's life in the American 'suburban refuge' of Kwajalein was less than a decade, but after we left, I experienced an intense homesickness that was only exacerbated by the shocking realisation that life for Americans on Kwajalein was only supposed to be a mere

4 Lauren Hirshberg, 2012, 'Nuclear families: (Re)producing 1950s suburban America in the Marshall Islands', Organization of American Historians Magazine of History 26(4): 39-43, p. 39. 
'tour of duty' and not a permanent place to settle. 'Tour' was the word that even American civilian contractors and their families, like mine, used to describe our existence in the Marshall Islands. And considering that civilians and their dependents have always outnumbered soldiers since the beginning of the missile-testing range (in the 1970s, there were nearly 5,000 American civilians living on Kwajalein versus a mere 20 employees of the US Army), 'touring' was a pun that was more suggestive of our leisurely lifestyle than it was an active defence assignment.

When I would hear kids at school on Kwaj talk about coming back for another tour, or my own parents speak about the end of our own tour, I presumed that we were talking about the idea that we were all on an extended holiday. Despite the smallness of our island we did, for instance, have two movie theatres, two swimming pools, yacht and country clubs, several pristine beaches, a golf course and multiple playing fields for every sport imaginable, a fully stocked supermarket, free snorkelling and scuba diving, sailing, water-skiing, and so onall on a tiny island in the centre of the Pacific Ocean. ${ }^{5}$ Every evening, couples holding hands and families with cameras would congregate in front of our lagoonside home to watch the sunset. We would even gather with popcorn and lemonade to watch the missile tests at night. We lived in comfortable, air-conditioned homes and rode around slowly on rusty bicycles. We had barbecues down by the beach. It was a tour, but we weren't exactly tourists. Or at least we took our tourism seriously.

Even if no actual tourist industry exists in Kwajalein Atoll, aside from the recreation services provided for personnel and their families, the dynamics of militarism and tourism mutually create and justify each other's existence there. This is rather like Teresia Teaiwa's idea of 'militourism', which she describes as 'a phenomenon by which military or paramilitary force ensures the smooth running of a tourist industry, and that same tourist industry masks the military force behind it' ${ }^{6}$

5 In recent years, the base also has its own Burger King and Subway fast food restaurants, which seem particularly out of place considering Kwajalein's tiny population and distance from the United States.

6 Teresia Teaiwa, 1999, 'Reading Gauguin's Noa Noa with Epeli Hau'ofa's Kisses in the Nederends: Militourism, Feminism, and the Polynesian Body', in Inside Out: Literature, Cultural Politics, and Identity in the New Pacific, ed. Vilsoni Hereniko and Rob Wilson, pp. 249-63, Lanham: Rowman \& Littlefield, p. 251. 
The touristic comforts of living on a beautiful Pacific Island, together with above-average remuneration and minimal cost of living, has always been a large part of what has sustained the American labour force there since the 1960s and given incentive for civilians-not only aerospace contract engineers from Raytheon, Lockheed-Martin, Boeing, McDonnell-Douglas, NASA, and other corporations, but also schoolteachers, architects, mechanics, department store clerks, cooks or lifeguards - to collaborate in supporting and shaping the military mission of weapons testing.

It has arguably also been the potential revocation of those pleasures and rewards that has silenced many Americans from speaking up about countless injustices against indigenous people over the decades, or even noticing any injustice to begin with. The ongoing tour of Americans at Kwaj marginalises Marshallese to the exotic fringes of US national security, all the while reinforcing American hegemony in the Pacific as natural and unquestionable. Even as a small boy, it was quite obvious to me that Marshallese people were not being accorded the same dignity that I enjoyed, nor were they seen for who they really were. Thinly veiled, racist discourses about Micronesians undercut the ideology of our world.

This is not to say that the reality of Kwajalein was in fact so clearcut and racist. Rather, ours was actually a rather diverse community, including a significant population of Japanese Americans and Native Hawaiians who had come to work from Hawai'i for the main contractor in the atoll. Our community included many African Americans and had a very open-minded attitude toward sexual minorities. Most of the adult population had a higher degree. Though there were some elements of segregation, this was not apartheid-era South Africa or the US South in the pre-civil rights era. There were also Marshall Islanders who lived on the island in higher-paid professional positions and had a deep rapport with the rest of the community, as were there some Americans who worked or volunteered directly in nuclear-affected Marshallese communities, some who spoke Marshallese fluently. Still, official American narratives and public discourses about Marshall Islanders rendered the fluidity and complexity of Kwajalein Atoll in stark black-and-whiteness, cultivating an attitude of apathy and endorsing orientalism. 


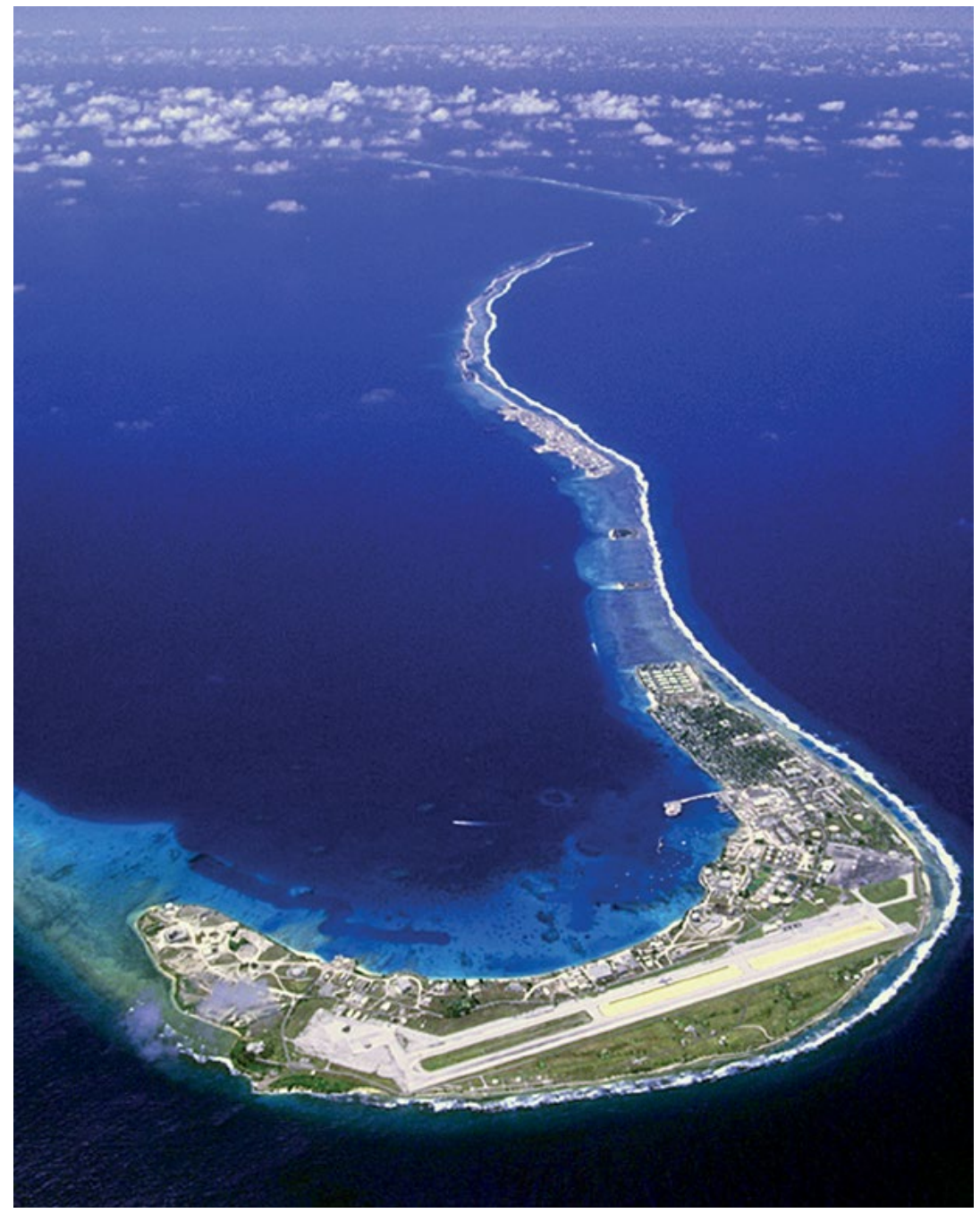

Figure 34. Aerial photo of Kwajalein Atoll.

Source. Photographed by official photographer, Sue Rosoff, 2000.

Marginalised and objectified by American discourses of science, development, politics, and racial difference, 'The Marshallese' were kept at a safe distance. Despite there being over 1,000 islands and 24 atolls in the vast archipelagoes of the Marshall Islands, to many Americans, all Marshall Islanders seemed to live 30 minutes away by ferry in the labour community that serviced our base, the crowded, tiny Ebeye Islet, just to the north of Kwajalein. It was within sight of Kwaj, on the same reef, reachable even by walking at low tide. It is the 
third island up the chain; it appears white on this aerial photograph because of its urban concrete sprawl. Marshallese on Ebeye were far enough away not to be threatening, but close enough to come and work for cheap pay. In casual banter, it was always 'The Marshallese' who were blamed for mismanaging their money - 'feudal' landowners who did not share the wealth they gleaned from US rental payments with commoners or Marshallese workers who squandered their salaries. It was always 'The Marshallese' who had an alcohol problem, despite the high rate of alcoholism in the American population and the enormous quantities of alcohol the base stocked for its residents. It was always the Americans who had what 'The Marshallese' lacked.

Strangers on their own land, the Marshallese I encountered as a child represented to me gaps in the green-lawn-picket-fence suburban vision the United States Army had painted onto the landscape of my childhood. I peered through that gap and saw those contradictions, even if I didn't understand them at the time. My mother participated in cultural exchanges with Marshallese women from time to time and also conducted research on Marshallese childbirth practices. My own visits to Ebeye were very rare, such as when we attended the kemem (one-year-old birthday celebration) of the son of a man who worked at the checkout counter in Surfway supermarket, or when we attended the annual Marshallese Christmas festivities. On such excursions, my parents would grasp my hand firmly as we disembarked the Tarlang ferry into the streets of Ebeye, cautioning me against touching anything dirty and lamenting that they hadn't made me wear closed shoes, lest I step in broken glass. But for me, Ebeye was vibrant, exciting, brimming with youth and overflowing with kids my age, unlike the eerie silence of Kwaj. I wanted to play with these children, and they looked back at me, sometimes beckoning me to join in their games, but we always had to hurry back to our ferry before nightfall. Their world was off-limits to me and obscured from view.

There were encounters on a daily basis, too. There was, for instance, the Marshallese man that worked as a janitor by the swimming pool, who would paint baby coconuts for me in colours of my choosing. Or there was our housekeeper Neitari, whom I would later consider to be my Bubu (grandmother). When I was six, I told her I would marry her. 


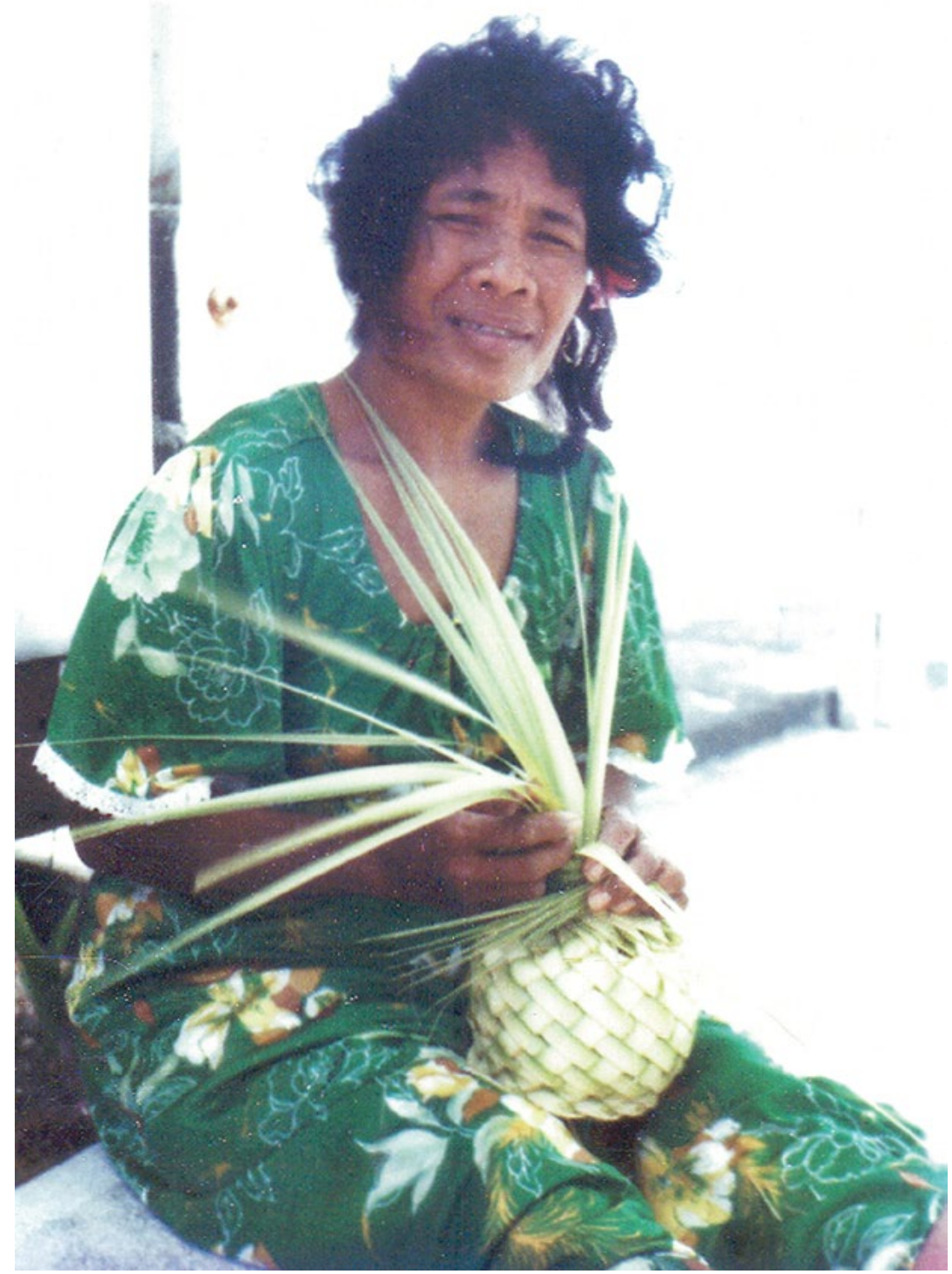

Figure 35. Neitari Pound in 1978 on Kwajalein.

Source. Photographed by Christine Dvorak; from the family archive.

Wandering around the island on my bicycle like most Kwaj Kids, I would veer off the beaten paths and make my own sense of the landscape. In practice, I may have lived the life of a tourist-settler child on a paradise island, seduced by our resort-like reality; in spirit, however, I was restless and burning with curiosity like many of my 
peers. I naturally saw beyond the contradictory utopia of our cement and grassy lawns to the deeper coral roots below, and I felt a visceral sense of belonging there, in spite of the military metanarratives of temporariness and distance from the American homeland. The breezes across the lagoon from other islets in the atoll haunted me with the perfumes of mythical flowers, the ghostly musk of death and buried memories, or the rotting stench of 'development' and broken promises. I played on forlorn Japanese wartime concrete bunkers that remained after the American amphibious invasion of 1944, bicycled between shiny new white radar globes and rusty atomic-age junk, and wondered often about the Marshallese workers who passed in and out of our American civilian community to toil by day as our carpenters, painters, maids and custodians and return by ferry every evening to the shantytown on Ebeye.

As a Kwaj Kid, these realities and rhythms, however unsettling or colonial they may seem, were associated with the idea of home in my mind, but they also conjured in me a yearning to know more. As geographer Yi-Fu Tuan argued, 'space' is something that becomes place, that 'what begins as undifferentiated space becomes place as we get to know it better and endow it with value'. 'The city or land is viewed as mother, and it nourishes; place is an archive of fond memories and splendid achievements that inspire the present; place is permanent and hence reassuring. ${ }^{8}$ Though bugged by my intuition to dig deeper and eventually return home to Kwajalein, it would take decades before I consciously became aware that my little hometown, so quiet and 'innocent' in its seemingly homespun goodness, was but a tiny speck precariously perched atop the unfathomably profound reefs of history in the Marshall Islands, and that it was a place that had different meanings to different people. My detours have only begun to scratch the surface.

7 Yi-Fu Tuan, 2003, Space and Place: The Perspective of Experience, Minneapolis: University of Minnesota Press, p. 6.

8 Ibid., p. 154. 


\section{The missile}

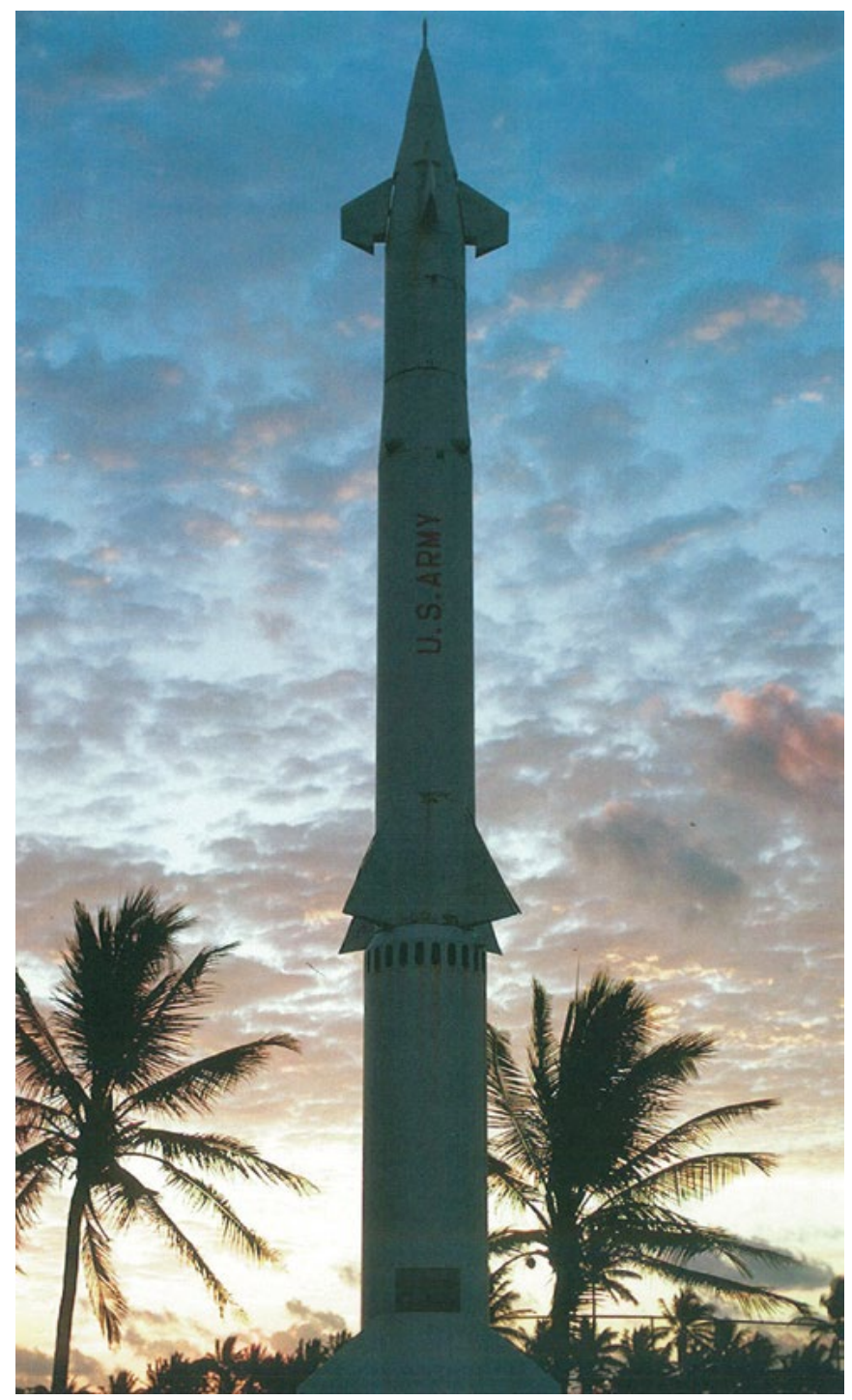

Figure 36. Kwajalein Missile Monument in 1977.

Source. Photographed by Walter Dvorak; from the family archive.

My father took the photo in 1977, probably early in the morning on his way to work. It is of a missile rising proudly against the sky, as if launching out of the sunrise, above the coconut palms and the fence of the softball field. This inactive rocket, neutered of its nuclear payload, 
stood watch over the little league baseball teams playing each other under the bright lights, and the Kwaj Karnival that happened in its shadow every year - a fair that included even a carousel and a ferris wheel. People would sit on its concrete steps watching sports, playing music by the Eagles or John Denver, drinking Olympia Beer as the sun set and the stars came out.

It was so ordinary and natural in its existence there on our ball field that we never questioned it. I remember hugging that missile to see if my arms would reach around it (they didn't), and how hot its white metallic skin felt in the midday sun, how its paint smelled. We would lean against it and pose for photos in our school yearbook. And at the same time, it was awesome, monumental, phallic, reassuringly pointing skyward to heroically defend us against The Enemy. It was a friend, a mascot, and an icon, and it bespoke the seamlessness with which our suburban Americana blurred into the Cold War. It symbolised, in many ways, the raison d'être of our existence on Kwaj and yet it was so central that we barely thought twice about it. According to an extensive Facebook page for former Kwaj residents, this missile was installed around 1965 and dismantled in 1991 after succumbing to severe corrosion that caused its fins to fall off and resulted in an overall safety hazard. Were it not for rust, this ubiquitous elephant in our living room would probably still be standing today.

Take this map from 1972 published by Bell Laboratories for newcomers to the island. 'Places to Go and Things to Do on Kwajalein' is a compact and easy-to-access guide to orient its users in a whimsical and carefree way to the pleasures and conveniences of our island home. It depicts Surfway Grocery Store (35), the barber shop (25), Coral Sands Beach (54), Emon Beach (47, appropriated from the Marshallese word emman, meaning 'good'), the Small Boat Marina (49), the scout camp (4), tennis courts (34), the Richardson outdoor movie theatre (9), and my elementary school (37). Aside from Launch Hill (1), which was also known as 'Mt Olympus', the numerous testing and tracking facilities sited on the other end of the airstrip are not mentioned at all in this map, nor are any of the Japanese structures remaining from the war, the mass graves of the fallen soldiers, or Marshallese sacred cultural sites. And as always, our friendly missile here is such a natural part of the landscape that it is drawn on the map but not even labelled. There it is, just to the left of the Grace Sherwood Library and the bowling alley (10). 


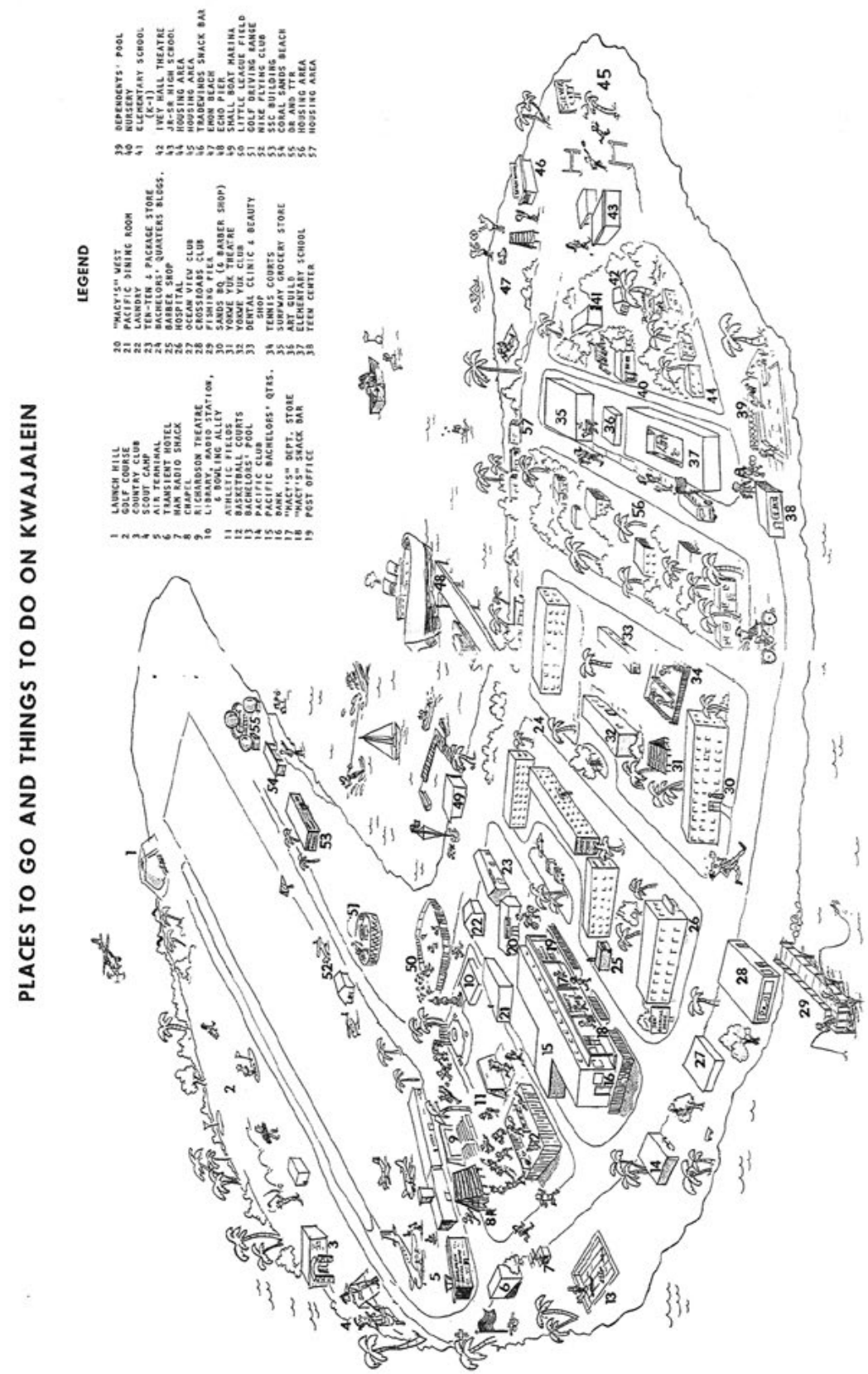

Figure 37. 'Places to Go and Things to Do on Kwajalein'.

Source. Bell Laboratories, 'Kwajalein Orientation Guide'. 
Like this map, the Kwajalein telephone directory is another sort of banal, everyday guide that relegates missile testing to the background. The 2001 Telephone Directory, for example, contains several pages of regulations and safety notices interwoven with cultural or recreational information; it is described as 'recommended reading', according to the base commander in his greeting letter published on the inside cover. He writes, 'Today, as in the past, the men and women of the US Army Kwajalein Atoll/Kwajalein Missile Range are performing an important mission, essential to the security of our country. I am pleased to have you join us, and I am confident that you will find your stay enjoyable. ${ }^{\prime 9}$ The recruitment to an important mission of missile testing and space operations is thus fused with expectations for an 'enjoyable stay' on the island, words that might be spoken by a hotel manager or cruise director. He orders the American Kwajalein employee both to work hard and to play, to devote themselves to the security of the United States, and to ignore whatever contradictions arise.

Throughout the text of the phonebook, various safety notices are printed that warn of the many perils of life on island and the importance of adhering to operational protocols, such as not discussing classified information over the phone. Repetitive in their clip-art banality, most users probably would not ponder these messages deeply, but stepping back and detouring the margins, one notices how the ideologies of national security naturalise weapons of mass destruction into everyday life. At the bottom of the same page that contains office listings for the Federal Aviation Association, National Missile Defense Agency, and Lockheed Martin, there appears a 'Safety Note', which warns of the hazards of gathering seashells on the reef and features a cartoon of a straw hat, sunglasses, boots, and tongs. ${ }^{10}$

9 US Army Kwajalein Atoll, 2001, 2001 Telephone Directory.

10 US Army Kwajalein Atoll, 2001 Telephone Directory, p. 40. 


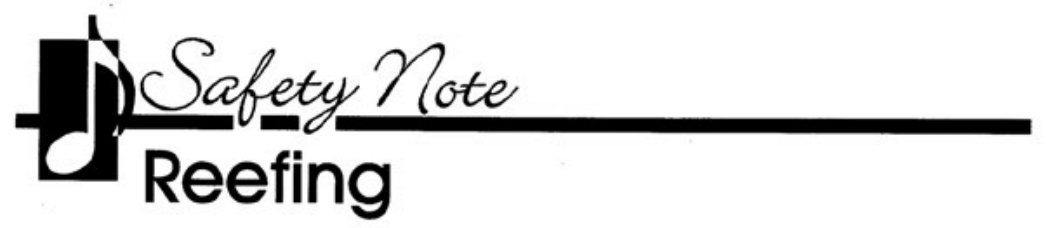

For your protection and comfort while reefing you should take a few simple precautions.

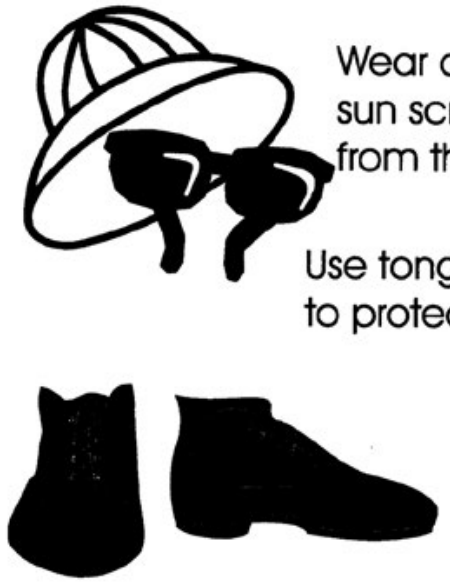

Wear sturdy shoes and socks to protect your feet against sharp coral, sea urchins, and jellyfish.

Figure 38. 'Safety Note'.

Source. US Army Kwajalein Atoll, 2001, 2001 Telephone Directory, p. 40.

It is in this style that the official tour of Kwajalein emphasises leisure as serious business, fraught with its own peculiar dangers. 'For your protection and comfort while reefing you should take a few simple precautions', the note nags. True to typical discursive practice regarding the 'mission' of the base, the contradictory activities of missile testing and reefing are thus packaged together as a matter of everyday domesticity. Defence-related offices are listed in small Helvetica print among food services and other ordinary items, boringly, not worthy of mention. Yet the danger (and thrill) of exploring the reef is advertised with much embellishment, illustration, and a significantly larger typeface, filling up two-thirds of the page. Like the missile monument on the playing fields, the directory thereby visually offsets and obscures the real perils of life on a high-security testing range and a former World War II battlefield in favour of more 
benign and tropical (albeit somewhat 'dangerous') pastimes, which it simultaneously flaunts and exaggerates to draw attention away from missile defence.

Not only does the official discourse of US power at Kwajalein maintain the double-edged tour of duty/pleasure at Kwajalein, it also elides Marshallese people from the picture and removes the American community from its geographical context in the Marshall Islands. Beginning with its establishment in 1964, the missile testing range even succeeded for nearly 40 years in ignoring the international dateline so that it could synchronise Kwajalein Atoll with the work schedule of the continental United States, a logistical tactic that the Republic of the Marshall Islands finally overrode in 1993 when it required the test site to standardise itself with the rest of the country. ${ }^{11}$ It has since rescheduled the work week within the US-leased islands to run from Tuesdays to Saturdays, but this time/place dislocation continues to disrupt the lives of Marshall Islander commuters, who are unable to prepare adequately for Sunday church services or take care of their families on Saturdays when their children are not in school.

The phone directory likewise dislocates residents of the American community into a special space that is removed from the Marshall Islands altogether. Personnel are listed, and thereby enlisted, to the official American tour by their name and company, with numbers that can be dialled by a local extension. There are extensive listings about how to call the continental United States and various military bases worldwide through military exchanges. Yet, despite their proximity, the telephone directory does not list any numbers or any instructions for calling any of the islands in the Marshall Islands beyond the military installation, not even Ebeye and the islands right next door.

\section{Homecoming}

It is 1982. My mother, baby brother, and I are on our way to the air terminal to say farewell to a friend who is leaving the island. We push our bicycles over the broad grassy field between that towering missile and the racketball courts, past the water silo and the baseball diamond. Assembled in the hot sun in all directions around the giant

11 'In Marshall Islands, Friday is followed by Sunday', 1993, New York Times, 22 August. 
shade tree by the chapel are hundreds of Marshallese people, mostly women - sitting, talking, weaving baskets, singing songs. There is a strange tension in the air, a feeling that there is something I don't quite understand here. My mother looks flustered, bothered by something.

'Why are all of these Marshallese people sitting here?' I ask.

'I'm not sure, but I think it's because they're unhappy about their land,' she answers.

'What do you mean?'

'I'm not really sure,' she answers.

We walk carefully around the edge of the crowd. I do not know what to say to them or how to react, but they feel familiar to me. Some of the women look up and smile at me. They remind me of the many women my mother has introduced to me, including the housekeepers who have taken care of me.

Coming by boat and camping at the south end of the island at Camp Hamilton, the place where my Cub Scouts troop holds its annual picnics, most of the protesters are women and children. Most men are afraid of losing their jobs or even being killed; it is the women who bravely stand up for the sake of their land and their children's future. ${ }^{12}$ American residents of Kwajalein know very little of what is happening even on the same island, but perhaps this is why my mother's expression looks so uneasy. The military guards are multiplying - they have been sent in from Hawai'i. They are cold, inflexible. The cashiers now ask for our badges in Ten-Ten Store. I've never had a badge. The guards stop even the American women who try to bring homemade food to the Marshallese protesters. What to make of this break in the narrative of our happy piece of paradise? What does this mean?

I had witnessed the beginning of Operation Homecoming, the biggest peaceful protest of the indigenous people of Kwajalein against the military occupation of their land without proper compensation. Under the blessing of Iroojlaplap (Paramount Chief) Lejolan Kabua, protest leader Handel Dribo, together with Irooj Imata Kabua, Ataji Balos and other leaders, almost 1,000 protestors would converge on Kwajalein and other islets, continuing a series of 'sail-ins' that had been increasing

12 This is according to landowner Ataji Balos, one of the leaders of the movement, whom I interviewed on 14 March 2005. 
in size since the 1960s. Many Marshallese in Kwajalein came to call these peaceful protests jodiks, cleverly dubbed after the Japanese word jōriku, meaning 'land invasion'. Making their own amphibious arrivals just as the Americans did in 1944 and peacefully reclaiming their land, Operation Homecoming was true civil disobedience, not unlike Martin Luther King's march on the lawns of the American capital in 1963.

These 'landowners' ${ }^{13}$ were protesting the United States government's 35-year military use agreement with the new national government of the Republic of the Marshall Islands, angry about having been removed from their small islands and forced to suffer miserable living conditions on Ebeye for far too long. They had already staged a major sail-in in 1979, when they disrupted the MX missile-testing schedule and demanded that the United States compensate them for having used their land since 1944 without their consent, a request that US negotiators furiously dismissed as a 'dead issue'. ${ }^{14}$ Anxious about the impending implementation of the Compact of Free Association with the United States, they were worried that their voices would be silenced by the new alliance between their government and Washington. Operation Homecoming was a massive mobilisation that asked for higher land payments under another shorter interim land use agreement that would enable landowners to have more control over the terms of this military lease.

Though Kwajalein Marshallese were immensely frustrated by four decades of American negligence and military occupation, theirs was a good-spirited and remarkably nonviolent protest that reflected the grace and patience with which they had endured their plight. Yet, the US Army response to their civil disobedience was one of reactionary and absurd paranoia. Marshallese activist Darlene Keju and her journalist husband Giff Johnson travelled to Kwajalein by speedboat from Ebeye during the military lockdown and press blackout in July 1982 to observe the situation. Johnson took a photo of protestors on

13 'Landowner' is a term that suits a western ideology more than an indigenous one in terms of Marshallese lend tenure, given the fact that vast extended families - between irooj chiefs, alap clan heads, and rijerbal commoners (literally 'workers') all are considered to share the land rights and each group is entitled to a respective third of the fruits of that land, whether it be crops, fish, or military lease payments.

14 Giff Johnson, 2013, Don't Ever Whisper: Darlene Keju-Pacific Health Pioneer, Champion for Nuclear Survivors, p. 397. 
the beach from the lagoon, knowing that any non-landowners would be arrested if they were to enter the military installation. ${ }^{15}$ It is an image of children happily playing in the crystalline blue waters of the beach while adults chat quietly behind them; but in the middle of the photo, an American police officer earnestly takes notes about inbound and outbound Islanders and perhaps also about the "child protesters' ${ }^{16}$

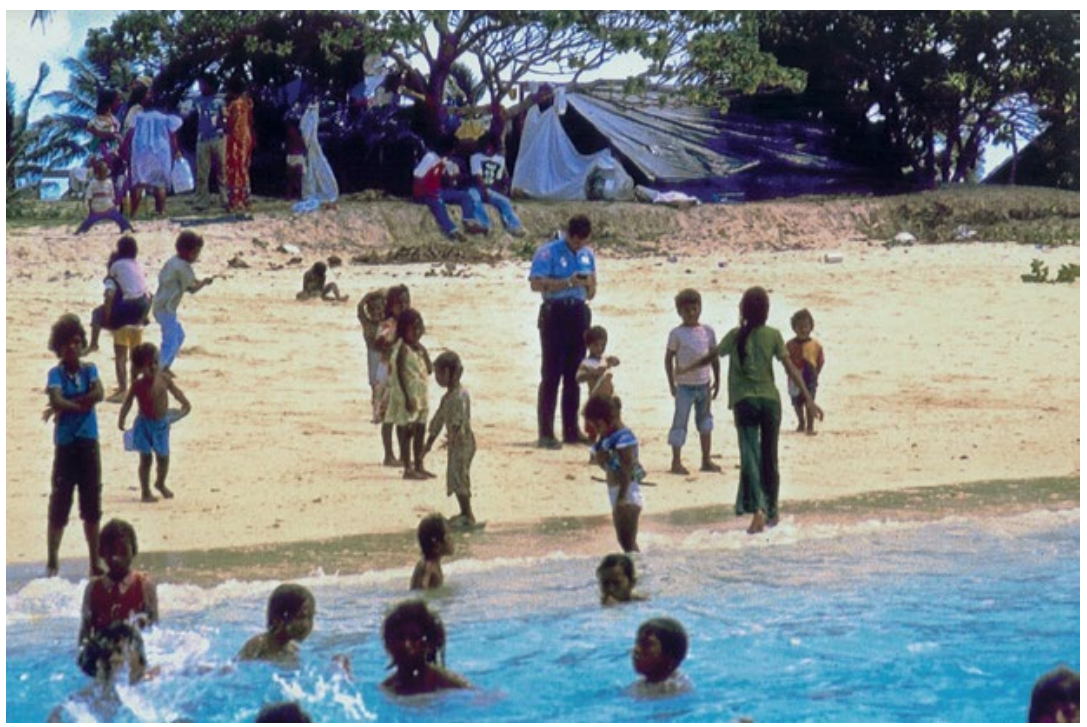

Figure 39. Operation Homecoming in 1982.

Source. Photographed by Giff Johnson, Micronesian Seminar Collection.

Keju would later speak about this at an international gathering of the World Council of Churches in 1983:

They took their women and children and they sat on their islands. Now you must remember, the US government has taken two thirds of our islands. It means we cannot go fishing. We cannot go to visit our islands and get more food for the [population of Ebeye] ... it means we're stuck into what we call a jail. Can you imagine? The United States government is only leasing our islands. And we have to have passes to go onto our own islands? ${ }^{17}$

15 Personal correspondence with Giff Johnson, 12 May 2014.

16 Johnson, Don't Ever Whisper, p. 107.

17 Ibid., p. 143. 
The protesters managed to sustain their presence on their ancestral lands until that October, in spite of the aggressive military response. In the months after the protest began, the US Army arrested leaders, prohibited 200 maids and groundskeepers from doing their jobs, conducted rigorous security inspections of, and confiscations from, all people entering and leaving the base, prevented all Marshallese from accessing their only bank (which was located on Kwajalein), and shut off toilets at Camp Hamilton, resulting not only in pollution for the campers, who used the beach instead, but for American residents as well. ${ }^{18}$

Under pressure to resolve these land disputes and activate the Compact of Free Association, which ultimately went into effect in 1986, First President Amata Kabua enacted his power as president to put all of Kwajalein lands under eminent domain, effectively foreclosing them in the public interest and forcing the new land use agreement to go through. ${ }^{19}$ This agreement would, in part, ensure major US infrastructure support to the new Republic of the Marshall Islands in exchange for permission to use the islands (especially Kwajalein) for strategic purposes on an ongoing basis. It was the beginning of what American and Marshallese leaders to this day call their 'special relationship', and the beginning of more discontent for the people of Kwajalein. ${ }^{20}$

My family's 'tour' at Kwajalein ended in June 1982, only a month before Operation Homecoming was fully under way and Giff Johnson's photograph was taken. We left not because of civil unrest; in fact, my family knew very little about what was unfolding. Our tour ended simply because my parents were ready to settle back in the States, to live close to our relatives. But even though I never quite felt at

\footnotetext{
18 Ibid., pp. 105-106.

19 David L. Hanlon, 1998, Remaking Micronesia: Discourses over Development in a Pacific Territory, 1944-1982, Honolulu: University of Hawai'i Press, p. 212.

20 These wounds would be reopened when the Compact was renegotiated in 2003, once again without full consensus from the landowners, who were offered only less than half the amount of compensation they proposed after a thorough land appraisal and assessment of their risks and long-term needs to sustain Ebeye. After threatening for eight years to deny further American use of the atoll and return to their islands, in 2011, Paramount Chief Imata Kabua and other landowners signed a 50-year land use agreement through to 2086, thus formally ending the stalemate and ensuring that suspended land payments held in escrow would not be returned to the US government. As President Christopher Loeak (then senator and spokesman for the Kwajalein landowners) said of the agreement, "The tide is not too high but it's not too shallow either. Where we are at today is a compromise which we've agreed upon to safeguard our future.' See Suzanne Chutaro, 2011, 'LUA signed after 8 years', Marshall Islands Journal, 13 May.
} 
home in the States, at least my parents had the option to make our 'homecoming' to New Jersey any time they wanted. The displaced landowners of Kwajalein Atoll have never had that luxury.

\section{Jambo}

It is January 2001, and heavy rains have engulfed the atoll of Arno. Having lived in the States and Japan, I have come back to the Marshalls after nearly 20 years away and am trying to learn more about the country beyond the fringes of Kwajalein. My friend has introduced me to his relatives, who kindly have welcomed me to stay with them. I wake up to the sound of chickens crying out as they escape the rain. Nine-year-old Robill comes in to call me to breakfast, rice with boiled chicken and grated coconut. When the rains subside, Robill and his friends pull at my arm to take me out for my daily Marshallese lesson, 'Kwoj jambo - wanna take a walk?' they ask. Jambo comes from the Japanese word sanpō, to stroll around, but it has an even broader usage in Marshallese - sometimes to take a trip, a random journey without any clear destination, a detour, perhaps.

I walk with the boys along the beach. The plants are all familiar to me- even if I do not know their names, I remember how their leaves feel, how their sap would taste if I were to chew on those twigs. Like these kids, I know how to blow on the hermit crabs to tease them out of their shells. And of course there are millions of things I don't know. They are all the same age that I was when I left Kwajalein, and all of them are as confident in their world as I was in mine. I have never played with Marshallese kids, I realise, not even when I was a kid myself. As we walk, they point at different objects and quiz me, 'Ta e-What's this?' I learn various words for coral sand in different stages of wetness and coarseness, baru for crab, bob for pandanus, $m \bar{a}$ for breadfruit. I learn to count from juon (one) to jibukwi (100).

It begins to downpour again and I chase the boys into the jungle where there is more cover. We find shelter briefly under the leaves of a banana tree and then race across the open yard of an old wooden house where rows of burlap sacks filled with copra are laid out for the next ship. We run up onto the porch where an old, skinny man is sitting in a rocking chair. He nods at Robill to grab me a seat, and we sit facing each other. He starts to speak to me in Marshallese at length, 
smiling animatedly and pointing at the lagoon. Then, realising I have barely any idea what he's saying, he knits his eyebrows and focuses on the Japanese characters on the t-shirt I happen to be wearing. 'Nihongo dekimasuka - Can you speak Japanese?' he asks, in flawless Japanese.

We proceed to speak in Japanese for several hours. He tells me about the crazy weather patterns, about schooldays during the Japanese times. He hesitates as he tries to tell me about his family and confesses that he does not know the word for 'grandchild' in Japanese, because he was too young to ever hear anyone use that word in the Marshall Islands. At this point it becomes clear to me that even though my new friend is probably in his 80s, he speaks the Japanese of a child, because that is how old he was when the war broke out, when the Japanese era effectively ended.

'I grew up on Kwajalein', I explain to him. He squints, trying to make out what I am saying until I enunciate Kuwajleen, the Marshallese pronunciation.

'Ah, so many people died in that atoll in the war, so sad,' he says. 'I had family there too. Sensō wa dame-War is bad.'

I look down at the 10 boys who have gathered curiously around us on the porch to watch as we speak in Japanese, not understanding a word we have spoken. They giggle as our eyes meet.

\section{Postcards and pilgrimages}

This Japanese postcard is from the 1930s, depicting the atoll of Jaluit in the Marshall Islands, which was once an integral part of the Japanese Empire, part of the Nanyō Guntō South Seas mandated territories that Japan was awarded in 1922 by the League of Nations. ${ }^{21}$ The Marshalls were, in fact, the first islands officially declared Japanese territory after Japan wrested Micronesia from Germany during World War I in 1914. Jaluit, which had been a major hub of German economic activity from the late nineteenth century, became the farthest eastern edge of the Japanese Pacific.

21 This postcard is an example of the ephemera I have found by scouring online auction sites in Japan. Few materials like this are available in archives or libraries, and most come from private collections. 


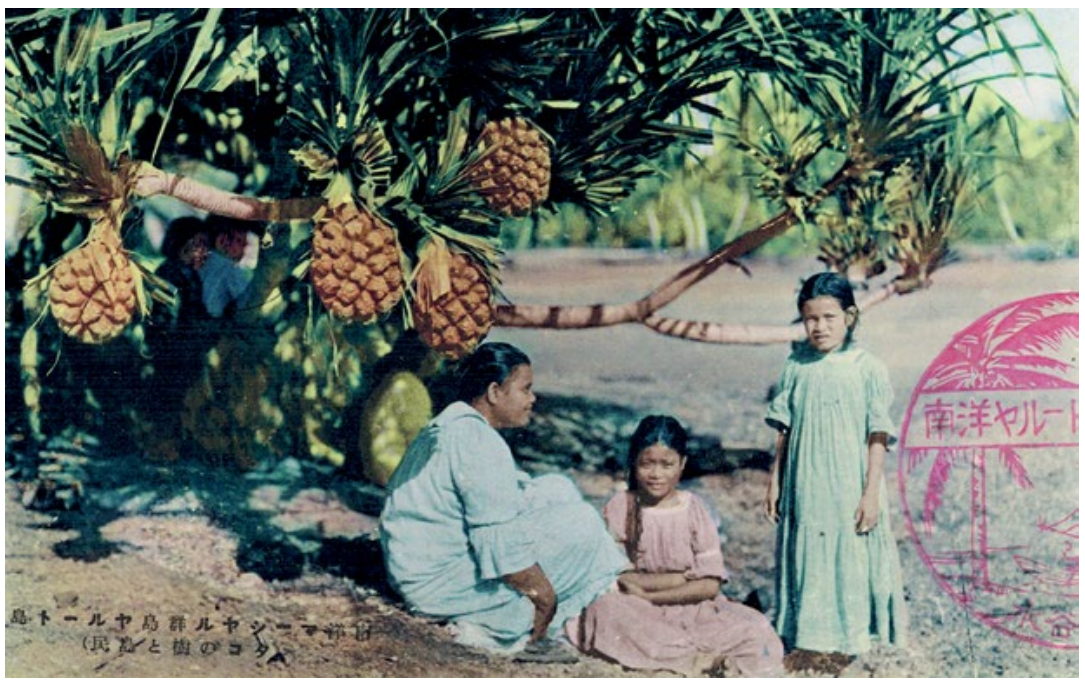

Figure 40. Postcard of Jaluit Atoll, Nanyō Guntō Mandated Islands of Japan, pandanus trees and Islanders, cancelled with Jaluit Post Office stamp, c. 1935.

Source. From the author's personal collection.

Postcards like these were printed for destinations all over Micronesia and depicted a wide range of island scenes, typically with Islanders posed in traditional dress. In this image, three girls sit on a beach, probably in the capital of Jabor Islet. The caption of the postcard reads 'Jaluit, Marshall Islands: pandanus tree and tōmin (Islanders)'. Touristic scenes like these were quite common projections that held currency in the Japanese public imaginary of the 1920s to 1930s. The Marshall Islands were, not unlike Hawai'i for Americans and Tahiti for French, also a site of wanderlust and desire. The trope of the available, virgin shūchō no musume (chieftain's daughter) was popularised by a satirical song of the same title, a romantic but racist musical tale of a Japanese man who falls in love with an island princess and tries to marry her but needs to learn local dances in order to win her hand. ${ }^{22}$ This image was propagated further by various versions of the song and different 'South Seas dances' or Nanyō odori performed all over Japan and later in the islands themselves.

22 Dvorak, 'Seeds from afar, flowers from the reef, re-membering the coral and concrete of Kwajalein Atoll'. 
Colonial desire for the South (not only the Japanese territories of Micronesia but all of Southeast Asia as well) was represented in boys' comics and games as well. A Japanese board game of sugoroku drawn by children's book illustrator Hara Yasuo and published in 1941 demonstrates this perfectly. Shown here (Figure 41), Nanyō Meguri Sugoroku $u^{23}$ is a game of conquest and adventure in which players trace the journey of a 'white' Japanese boy who departs Yokohama on a seaplane (1), passing volcanic Urracas Island in the Northern Mariana Islands (2), climbing pandanus trees (3), examining stone money in Yap (10), cooking with breadfruit (15), looking at a Palauan meeting bai or meeting house (19), and visiting a Japanese school for 'natives' (dojin, a word that was already politically incorrect at the time this game was made). Ultimately, a player wins by rolling the dice to arrive first at the epicentre of Japanese civilisation in the Nanyō Guntō, the Nanyō Shrine of Koror, Palau, a massive site that was dedicated in $1940 .{ }^{24}$

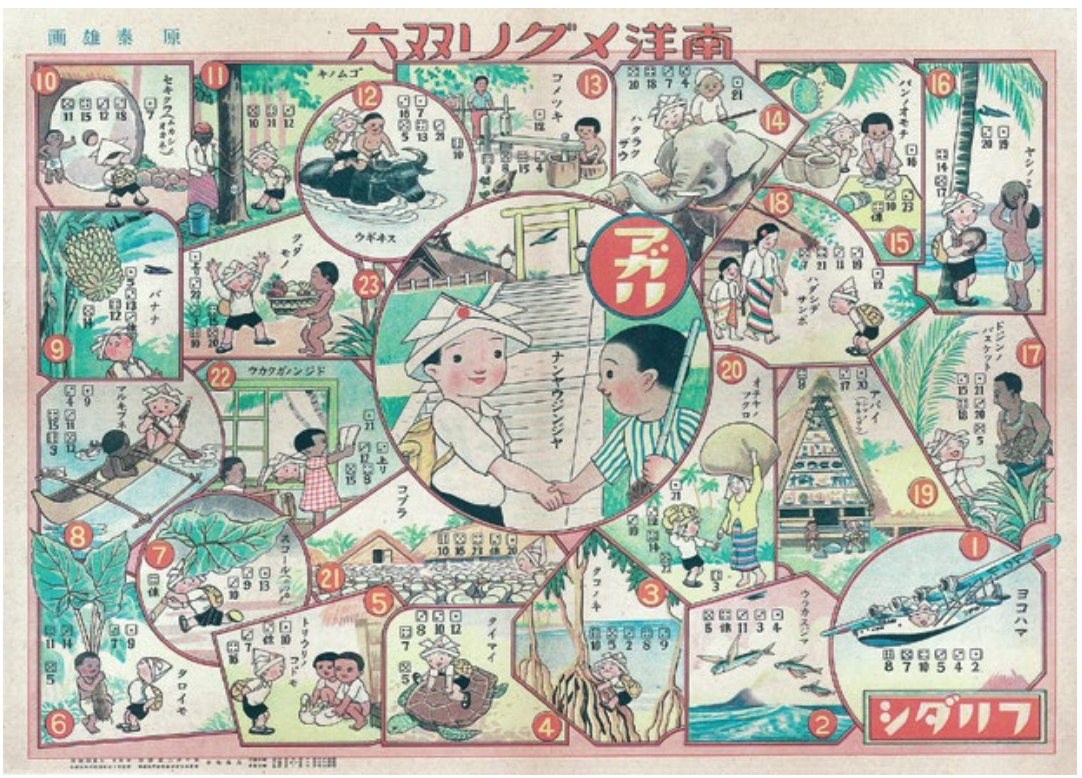

Figure 41. Nanyō Meguri Sugoroku board game.

Source. Illustrated by Hara Yasuo, published by Futaba Shobō, Tokyo 1941.

23 I found this board game quite by accident in an antique shop in Kyoto, where it had been preserved in a plastic wrapper and taped to the ceiling. As it is quite large, I had it professionally scanned at a high resolution.

24 Donald R. Shuster, 1982, 'State Shinto in Micronesia during Japanese rule, 1914-1945', Pacific Studies 5(2): 20-43, p. 27. 
Visions like these inscribed the Nanyō Guntō territories as carefree sites of leisure, adventure, and pleasure, and more importantly as safe, comfortable sites to which one could relocate one's family and start a new life. They were compelling enough to draw up to 96,000 migrants to the region from Japan by 1942 - mostly to the major populations of Saipan and Palau. ${ }^{25}$ Even in the Marshall Islands, the number of Japanese civilians was reported as nearly 530 individuals living in Jaluit in 1939, a number that certainly was small compared to over 10,000 Marshallese living in the atoll that same year but significant enough to be felt in the small main island of Jabor. ${ }^{26}$

Not only in Jaluit but all throughout the Marshall Islands, Marshallese who grew up before the 1940s make a clear distinction between the war years and the civilian Japanese times that preceded them. ${ }^{27}$ Those 30 years before 1944 are remembered with a sense of bittersweet nostalgia, not only for good schooling, health care, and opportunities for economic advancement, but also for the nostalgia of new products and foods like rice, canned food, or shaved ice, and a whole new wave of popular culture, from samurai films and music to sumo wrestling and baseball, which is still referred to in Marshallese by its Japanese name, yakyū.

Kwajalein Atoll had only a handful of civilian Japanese residents prior to its transformation into a military base, but with its schoolhouse, a number of shops, and frequent visits by copra ships, Islanders were already very exposed to Japanese people. In 1939, however, the Nanyō command headquarters initiated construction in Kwajalein Atoll, with the intention of transforming it from a rural copra-trading outpost into one of the most important naval air bases in Eastern Micronesia. ${ }^{28}$ The civilian government, including the school and its teachers, and all of the students, were relocated to Namu Atoll. This dramatic change was the first time that the people of Kwajalein were displaced from their land, but many were also offered jobs working for the military throughout the atoll.

25 Brij Lal and Kate Fortune, 1999, The Pacific Islands: An Encyclopedia, Honolulu: University of Hawai'i Press, p. 238.

26 United States Chief of Naval Operations (USCNO), 1943, Military Government Handbook OPNAV P22-1: Marshall Islands, Government Publication, p. 19.

27 Lin Poyer, Suzanne Falgout and Laurence Marshall Carucci, 2001, The Typhoon of War: Micronesian Experiences of the Pacific War, Honolulu: University of Hawai'i Press.

28 Mark Peattie, 1988, Nan'yō: The Rise and Fall of the Japanese in Micronesia, 1885-1945, Honolulu: University of Hawai'i Press, pp. 250-51. 
As Kwajalein and Roi-Namur in the north of the atoll were fortified, the Japanese military population swelled to several thousand men, most of whom - unlike the settlers who came before them-knew nothing about life in the Marshall Islands, let alone how to survive on a tropical island. Not unlike the American soldiers who would follow in their footsteps after their defeat, they had little interaction with indigenous people in general, and like the American community I grew up in during the 1970s, they also lived in their own sequestered world, drank sake, and bathed in Japanese-style communal hot baths. Some of these soldiers would eventually be transferred to other tours of duty, but as the war began and the Marshall Islands heated up as the front lines of defence for the entire Japanese Empire, many soldiers started to see their tour at Kwajalein as a mission of no return.

$\star * *$

It is 2005, and I am back on Kwajalein as a doctoral student, together with 20 Japanese elders from the Marshall Islands Bereaved Families Association of Japan. We have come to the atoll for one of the group's regular pilgrimages of ireisai, memorial ceremonies for the souls of the fallen Japanese soldiers who died in the American invasion of Kwajalein in 1944. This is yet another kind of tour, I soon realise.

After breakfast in the cafeteria where Marshallese servers at the buffet counter dutifully heap our plates with scrambled eggs, we board a white bus labelled 'US ARMY' and depart the Kwaj Lodge transient hotel. Some of the elders are dressed in funereal attire; others wear khaki adventure outdoor clothes and vests, as if on safari. After everyone has found a seat, their professional guide from a Tokyo travel company bows to the group with the conciliatory smile of a funeral director. Over the roar of the bus engine, he uses very polite Japanese to announce to us that today's itinerary will begin with a formal ceremony followed by a bus tour of the 1944 battlefield upon which the group's loved ones perished.

We ride to the southern edge of the airstrip, past the pond where I used to feed the sea turtles and down toward the hilly landfill I used to climb with my father and pretend it was a mountain. Passing the big missile-tracking radars and antennas, we reach the memorial, which is labelled 'Japanese Cemetery'. For these families, however, the remains of the soldiers and sailors who died in Operation Flintlock are in various places on different islands, and in the sunken ships 
at the bottom of the lagoon. Only a fraction of unidentified remains have been repatriated to Japan. For the bereaved Japanese families of Kwajalein war dead, the entire atoll is a cemetery, and our memorial tour is not one of mere war commemoration but rather an opportunity to commune with and console the spirits who have been here ever since the war.

A slender old woman with white hair and dark sunglasses taps me on the shoulder. 'See those trees?' Satake Esu asks me, pointing to two enormous Japanese pine trees towering over the bland off-white Kwajalein Range Services Photo Lab and the small memorial. Of course I know those trees - I used to ride past this memorial on my bicycle as a little boy.

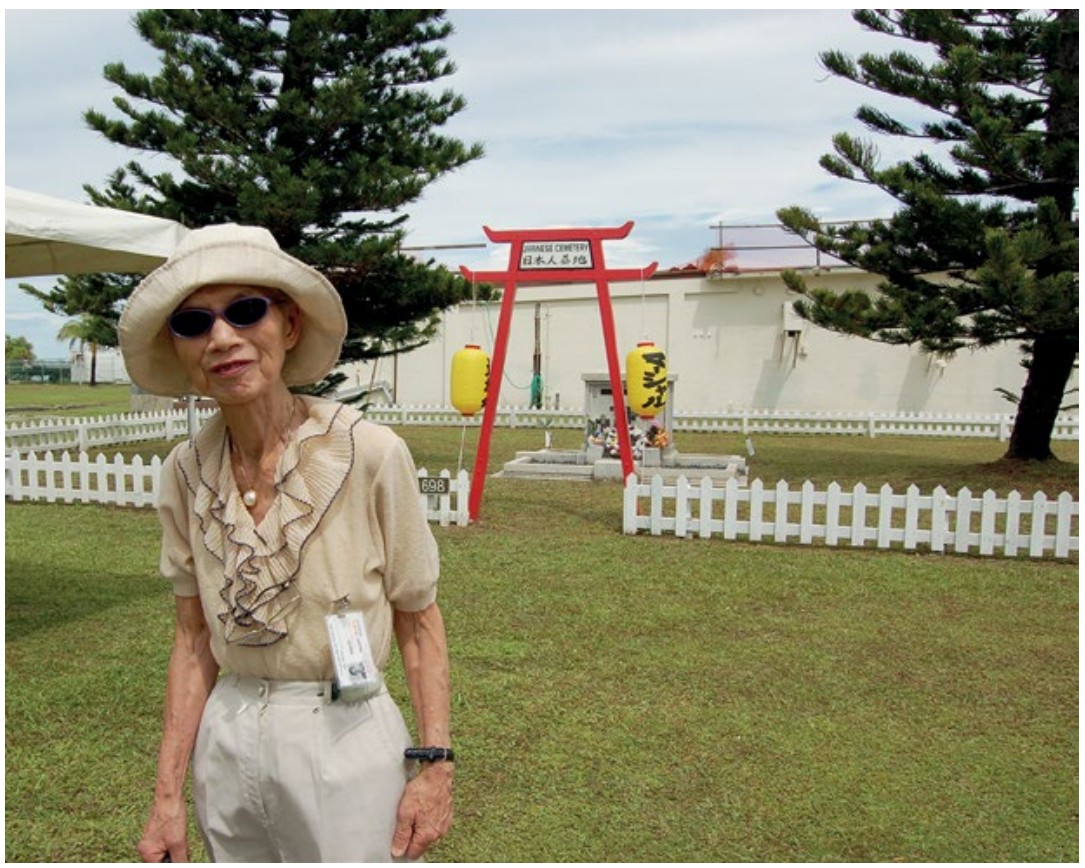

Figure 42. Satake Esu visiting Kwajalein Japanese Cemetery in 2005.

Source. Photographed by Greg Dvorak, 6 October 2012.

'Well, I was the one who planted those in 1975 when they were just seedlings, the first time we ever got to get off the plane here on the base and came here to mourn. You must have been two then ... andcan you help me with this?' She holds onto her hat as she lassoes a loop of twine over the red torii gate of the Japanese Cemetery. She 
ties it to a large yellow paper lantern that reads, Māsharu-hōmen Izokukai, 'Marshall Islands Bereaved Families Association'. Other members string American, Marshallese, and Japanese flags across the cemetery site.

'I'm in my 80s now but I was only married two months, you know,' Esu continues, 'and back in those days you had to be a "good wife" and just listen while the men did all the talking, and my husband was in the Imperial Army and he'd come and go all the time and never quite tell me what he was up to, even if I asked. All I knew was that he was a pilot. And being a good okusan (wife) I told him that if he ever got captured by the enemy, well ...', she makes a fist and grins stiffly, 'you'd better blow yourself up with a grenade or otherwise make sure you die before they kill you first.'

'Ima da to shinjirarenai koto dakedo ne-I couldn't believe I said all those things back then', she sighs and props up her dark sunglasses,

but several years after he was killed here in this atoll, I regretted it so much .... and so I found myself wanting to do something for life. So I became a doctor, and I started going around the world campaigning for peace. I've been everywhere. I was just in Iraq a couple years ago. You know, we have to remember how bad war is. We have to remember how all these boys died out here. Most people have forgotten, you know.

Esu grabs a large handful of incense sticks and plugs them into a pot, and several others lay out family photographs in front of the memorial to show to the spirits. There are also letters and notes, children's artwork - the kinds of things one might send to a loved one living far away. Esu takes a plastic branch of artificial maple leaves and places them on the altar as well, explaining that it is fall in Japan and the soldiers must miss the cool weather.

'And some flowers,' Esu says, placing a bouquet of plumerias that she has just picked from a nearby tree, 'to represent all the pretty girlfriends you boys never got to have.' 


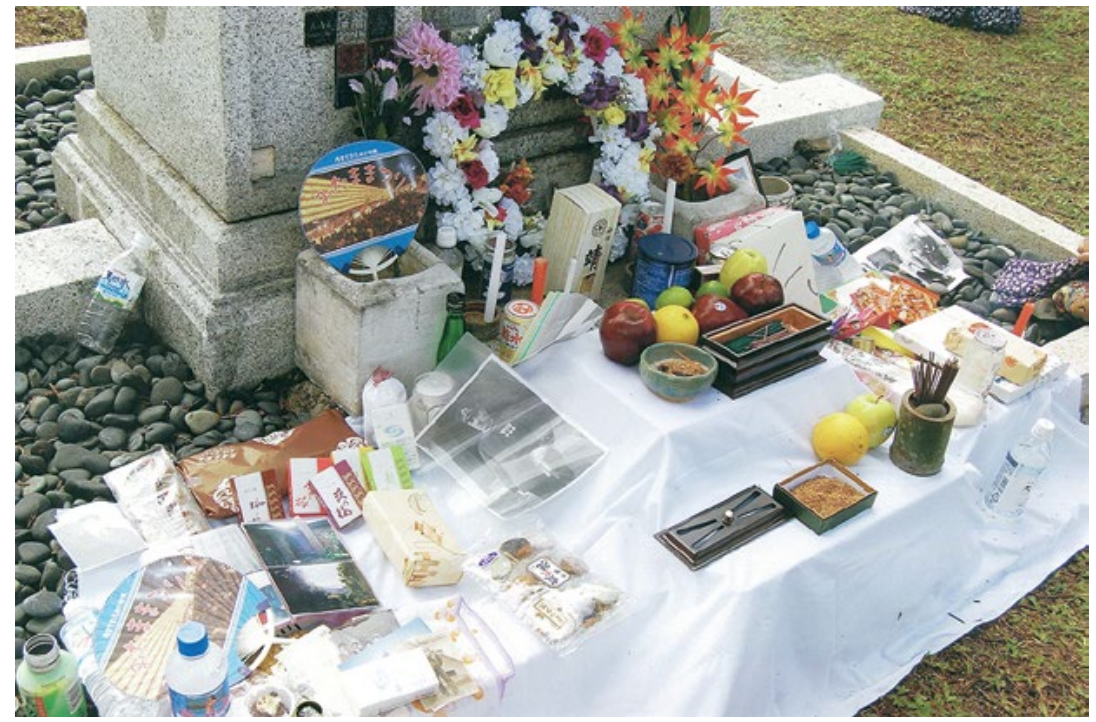

Figure 43. Offerings from bereaved families at the Japanese War Dead Memorial in 2005, Kwajalein.

Source. Photographed by Greg Dvorak, 6 October 2005.

The families begin their ceremony by singing the Japanese national anthem and a series of songs like 'Umi Yukaba' (If I Go Away to Sea) and 'Sayonara, Yashi no Shima' (Goodbye, Island of Palms), both melancholic melodies with lyrics about leaving home and never returning. Many of the mourners cry as they sing together, facing the memorial as if they were looking into the faces of the lost soldiers.

This is followed by a long Buddhist chant, after which the other 20 bereaved individuals come up one by one, entering the small white picket fence, passing through the torii gate, and approaching the granite memorial as if it were a gravestone.

'Oyaji — Dad!' one man shouts as he stands, trembling as he holds out a letter with two hands. It is apparently his first visit to Kwajalein. 'Father, I have finally come to the place where you died, this place where they made you come all by yourself, leaving your children and your wife behind. You must have been so scared, father, but you came here to this island of palms so bravely!' he shouts, his voice breaking. 'Thank you for everything, Dad-Oyaji, arigatō!' 


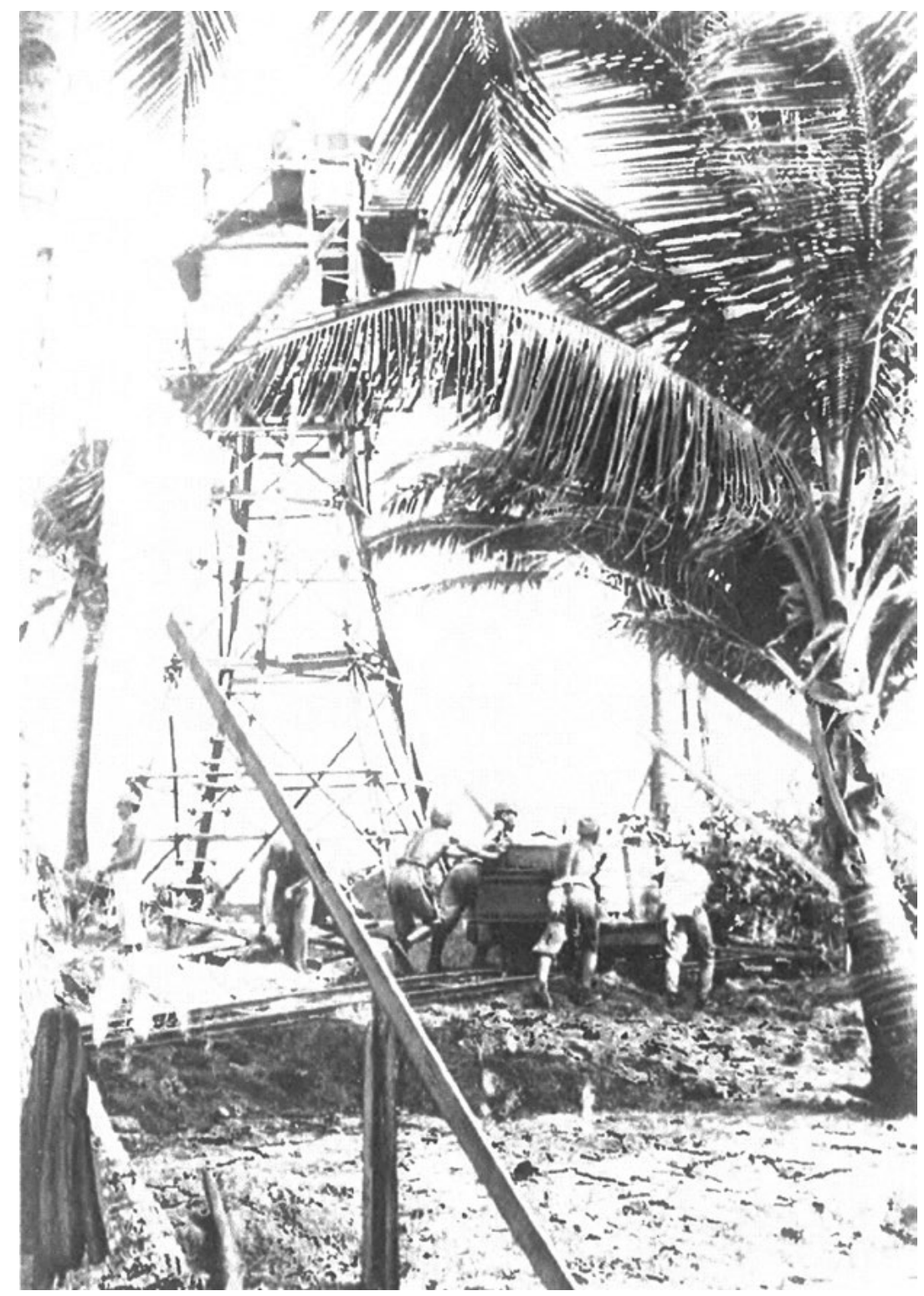

Figure 44. Japanese and Korean military construction corps workers building the base at Kwajalein, 1944.

Source. Image from Hitotsubashi University Archives, unknown origin.

After the ceremony, our battlefield tour begins near the memorial, where the group assembles under the palm trees. The guide gestures toward the impressive sight of cargo planes lined up on the tarmac far 
in the distance. 'Japanese engineers built this runway before the war', he explains, 'and they designed it so that it would act as a freshwater lens to supply water to the soldiers who were posted here.' The elderly pilgrims all nod their heads and make sounds of approval. They are probably unaware that prior to the building of this airstrip this area was once a wooded area that contained an important chief's house, a Marshallese cemetery, and the Japanese schoolhouse. But they do not see these things, for their eyes are set only upon a tragic landscape of battle and loss. They also probably do not realise that the bulk of the work done to build this airstrip and many of the fortifications around the atoll was conducted by hundreds of Korean laborers who were forcefully drafted by the Japanese military from the countryside near Busan and other regions and brought by ship to Kwajalein to work in the blazing sun. The setsueibutai, or construction corps, were mainly made up of these workers, seen here (Figure 44) on Kwajalein in January 1944, the month that the American invasion would take place. Here they push supplies along a narrow-gauge railroad, one of the techniques used to haul heavy materials across rough terrain or even across the coral reef between islands.

The road where we stand, the guide explains, was once the beach where American marines made landfall on the island when they launched their assault from neighbouring Carlson (Enubuj) Islet. He unfolds a pamphlet written in English, marked up with highlighter pen and Japanese notes. It is the 'World War Battlefield Tour' brochure published by the US Army Kwajalein Atoll. It begins with a block of text that describes 'Kwajalein Before World War Two', which charts a narrative that begins not with thousands of years of Marshallese navigation and settlement but with Spanish exploration in 1542 and German conquest of the Marshall Islands, followed by a very brief mention of Japanese capture of the islands. Japan's extensive 30-year civilian involvement in the islands is barely addressed:

Germany's commercial interest in the Marshalls led to their purchase from Spain in 1885. Imperial Japan, as a member of the Allied powers during World War I, quickly seized the islands from Germany in 1914. Japanese control of the islands, despite a strong protest from the United States, was formalized by the League of Nations in 1920, whose members permitted Imperial Japan to retain the islands under a class ' $\mathrm{C}$ ' mandate which allowed no naval or military installations. 
The Japanese presence in the Marshalls was of grave concern to American military officials, because the islands provided sheltered bases from which Japanese ships and planes could interdict the American supply lines to the Philippines, at that time an American colony. ${ }^{29}$

The pamphlet justifies the overwhelming American attack on Kwajalein by explaining that Japanese colonialism was a nuisance to American links between the West Coast, Hawai'i, Guam and the Philippines - portraying American hegemony as the only rightful form of colonialism in the Pacific. It describes the amphibious invasion of Kwajalein Atoll and the rest of the Marshalls as nothing more than 'a textbook operation' for American cadets to study and celebrate. It is this 'liberation story' of Kwajalein that dismisses Japan's prewar decades of peace and prosperity in Micronesia, at the same time it buries the narratives of Japanese, Korean and Marshallese survivors or memories of war dead. The battlefield tour pamphlet leads us seamlessly from reef to reef, from the landing at one end of the island to a nondescript mound of dirt covering a Japanese concrete emplacement, known as 'Bunker Hill' at the other end, where the 7th Infantry Division finally defeated Japanese forces in the south of the atoll and where we used to play hide-and-seek as children. It is a story in which the Americans are the heroes, the Japanese the villains, and Koreans or Marshallese nothing more than silent bystanders caught in the crossfire.

Standing on the golf course near a concrete pillbox, one of the elders asks, 'So how did my brother die, exactly? Do you think he even knew what was coming?'

The guide keeps his professional composure and, pausing momentarily, answers politely, 'We will never know that, I suppose, but this pamphlet says that the Japanese were expecting the Americans to strike elsewhere in the Marshall Islands, and so they were caught off-guard when they were overwhelmed by such a massive invasion. But I'm sure they put up quite a fight.' He flinches briefly at the sound of a golf club hitting a ball nearby, but his well-practised sympathetic smile lingers for awhile, as if to emphasise these are questions best left unasked. 
The elderly visitors get back onboard and stare out the windows quietly as the bus chugs back around the island, passing the airport and the island chapel, the church where our good old family friend used to be pastor. There is a stained glass memorial there that depicts an American soldier earnestly bent on one knee, his head raised to the US flag and heaven, hand over his heart, his back to the Marshallese flag. We pass George Seitz Elementary School, where I once learned reading and arithmetic; the commander's house; the Kwajalein JuniorSenior High School; the rows of 'new housing' at the northern tip of the island from which one can see Ebeye; and back past Emon Beach, where I used to swim every day after school.

As we walk from the dining hall after dinner that evening and the sun leaves streaks of salmon pink in its setting wake, the Southern Cross rises above the playing fields - the same fields where the Kwaj Karnival happened each year, where that missile once stood, and where Operation Homecoming began. The Japanese visitors excitedly remember how their husbands, brothers and fathers used to write home about the constellation in their letters and postcards from the Marshall Islands; even the logo of their organisation is the Southern Cross, minamijüjisei, on a turquoise background. As the group members try to hold still to take photographs in the dark, the guide explains, 'This area was close to the Japanese Imperial Admiralty. It's where most of the soldiers and the top-rank officers of this base lived and worked. Perhaps it is also where many of them left this world.'

It is surreal to hear these familiar elements of my military-engineered childhood suburbia described as part of the saccharine monologue of a professional Japanese tour guide, as if we were visiting the major sights of Kyoto. It is stranger, however, to hear the landscape described as if neither its American crust nor Marshallese roots even existed. And imagining it all as if it were frozen in 1944, I, too, can see the ghostly layer of the island through the eyes of these pilgrims, and smell the smoke and the death blowing on the night breezes. It is as if over 60 years have not passed and the Battle of Kwajalein took place only yesterday. 


\section{The special place}

My detours of Kwajalein always seem to end in the same place, as they do today in 2016, in a small picnic area on the ocean side of the island where my father and I shared a basket of sandwiches together on a windy day when I was seven years old. My father, the sole reason for our original crossing to Kwajalein Atoll, died in 1999 of cancer. His battle against his devastating disease, like the fight of the Japanese defenders of the atoll, was short but unwavering. Even though I said goodbye to him in New Jersey it was in part his death that precipitated my journey back to uncover the unanswered questions of my formative years. In the 10 or so times I have returned, and in the course of my research, I have realised how little I knew about Kwajalein and how little I even knew about my own father or what he did there.
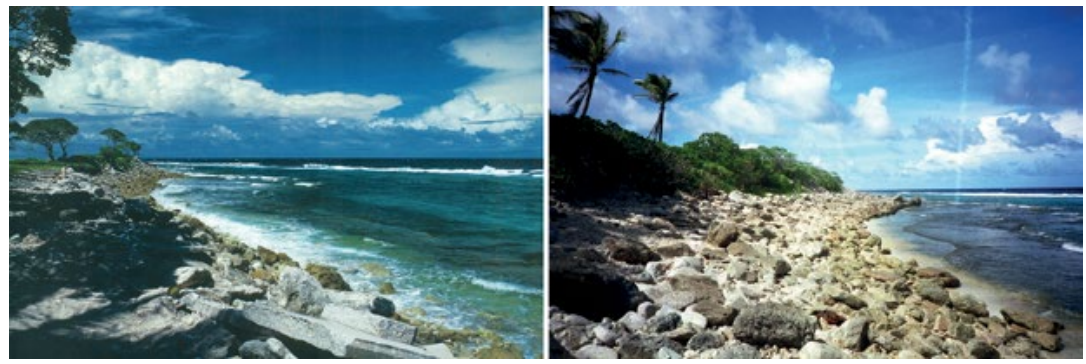

Figures 45 and 46 . The special place.

Source. Photographed by my father in 1979 (left) and by me in 2001 (right).

We called it our 'Special Place'. It is a small shady enclave alongside the runway, with a rusty old picnic table in a grove of palms, and a breathtaking view of the reef, the drop-off, and the open ocean. The decaying mouldy air terminal is within view in one direction, as is the old country club that still hosts parties today. The Special Place is not far from the site of the legendary utilomar flowering tree in Marshallese cosmology that symbolises the abundance of the islet and the reason why so many voyagers came from around the world to harvest the atoll's many flowers. ${ }^{30}$ Since the deep time past it has also been part of the land parcel ( $w$ to) known as Lo-pat, where heavenly bodies land, which is why elders say it eventually became the landing

30 Laurence M. Carucci, 1997, In Anxious Anticipation of Kuwajleen's Uneven Fruits: A Cultural History of the Significant Locations and Important Resources of Kuwajleen Atoll, Huntsville, AL: United States Army Space and Strategic Defense Command, p. 50. 
point for airplanes. ${ }^{31}$ During the war it was where Japanese soldiers would hide during the bombardment; later, it was from its offshore reef where Americans would mine coral gravel to rebuild and expand the Japanese airstrip for onward invasions. After the war, it was the edge of the Marshallese labour camp that was later removed in 1951 from the island during the atomic testing program at Bikini and Enewetak. This removal was in part because American authorities saw this Marshallese presence as an 'eyesore'.$^{32}$ Later, this precious Marshallese land became the first American boy scout camp and the entrance to the golf course.

Coming back is never easy. It involves asking friends on island to sponsor me and waiting for military approval, flying for two days and spending large amounts of money. Each time I return, although the atoll itself is its same familiar self, the atmosphere on Kwaj is always different. In 2016, it is tense and strange in the airport, as the military police brief us on new rules and regulations to comply with their latest perception of danger in the world. Now all non-American visitors to the atoll, even if merely transiting briefly from the only airport (which happens to be on the base) to Ebeye or other islands in the sovereign Republic of the Marshall Islands, must be scrutinised, their names and biometric data-fingerprints and iris scans - recorded in a database. Though the US only leases parts of the atoll, for all extensive purposes, this is America now.

After crossing through the discomfort of the checkpoints at the airport and dock, I come back here to this picnic place to be with my father. I sit on the grass and watch the ants walk over my feet, feel the trade winds pummel my body, and I sense his presence. I imagine him waiting for me in the Special Place, wearing that sweaty bright orange mesh 'Kwajalein Missile Range' cap, his nostrils flaring as he eagerly breathes the fresh air, as fascinated with the sea as he is with the aeroplanes that take off nearby, imbuing in me his reverence for both nature and technology, both the coral and the concrete. My father teaches me to open up to the contradictions, to see them squarely, to ask questions, and to teach my students to do the same.

31 Ibid., p. 195.

32 Jack A. Tobin, 1954, Ebeye Village: An Atypical Marshallese Community. Majuro, Marshall Islands, photocopied report in University of Hawai'i Library Pacific Collection, p. 3. 
Surely, my father knew very little about these histories, but he had great respect for the Marshallese people he knew, many who immediately remember him fondly when they see me and notice our resemblance. As an engineer, he loved the mysteries of the machinery with which he worked, and he did his job with the commitment of defending our family and our country. The engineers of Kwajalein who test these weapons and work with space surveillance are mostly people like my dad was - men and women who earnestly believe in what they do as a vital part of securing global stability. Landowners and other leaders in the atoll also assert their own agency in this relationship by asserting that the biggest export of the Marshall Islands is indeed world peace. But the flip side of this is that the legacy of war, nuclear weapons, and missiles - together with all the trauma they causedare what made our presence at Kwajalein possible in the first place. And the perpetual paranoia and vigilance about unseen foes that has lasted from the Cold War to the War on Terror is, by its very nature, the antithesis of peace. As former protestor, teacher, and minister Julian Riklon once said of the ongoing military use of Kwajalein, 'The Americans were among the first to bring the word of God and [to teach us] how to love one another. It's funny, because today they are telling me that I should have enemies, something totally different from what they first taught me. ${ }^{33}$

The curse and potential gift for me in being a Kwaj Kid has been wondering how to reconcile the genuine love for my father and my memory of home with the deep, dark contradictions of the past and present. I have had to learn that the nostalgic story of my childhood landscape is intertwined with a silent kind of violence that persists into the present day. As Vincent Crapanzano wrote of white memory in South Africa:

We play with our stories in ways we cannot with the violence itself. We cast ourselves as heroes or anti-heroes, men and women of delicacy and sensitivity or crudeness and insensitivity. We participate in our stories, identify with the protagonists we create, or disengage ourselves from them ... For the listener and the storyteller the stories and tales of violence are a kind of rehearsal for stories and tales of the future, which may have to be lived as well as told. They give cover to the terrifying silence of the pure act. ${ }^{34}$

33 Adam Horowitz, 1990, Home on the Range, Equatorial Films.

34 Vincent Crapanzano, 1985, Waiting: The Whites of South Africa, New York: Random House, p. 238. 
Detouring Kwajalein is difficult work that demands I listen to that 'terrifying silence' of that violence - to bear witness to the harsh contradictions that unfold before my very eyes. It demands a sensitivity to what lies beyond the breathtaking sunset and the turquoise lagoon, the manicured lawns and beaches and palms, to see what Mark Gevisser calls 'the history of pain in beauty' ${ }^{35}$ Unlike Gevisser, however, who writes triumphantly of being able to marry another man of another race in post-apartheid, post-marriage equality South Africa, I cannot go back home and revel in a sense of reconciliation. Our detours as Kwaj Kids require vulnerability, humility and the realisation that perhaps true reconciliation may never be possible, at least when so many of these contradictions persist.

My returns to Kwajalein in mind and body fill me with ambivalence, but they are not tragic visitations of sadness and regret like those of bereaved Japanese pilgrims; they are, rather, demarcations in my own growing and learning process. But my visits are fraught with the uncertainty about whether the military will even grant me access, filled with nostalgic delight, and frustration over the continuing problems I witness and my own inability to fix anything. There is also still immense joy, the laughter of children and the dancing and singing of Christmas time on Ebaye - the celebration of life itself. ${ }^{36}$

I wonder, too, would my father be angry with me for asking the questions I have asked, for criticising the work he did so earnestly, for daring to implicate our family in the drama of war and empire? Does it matter?

My visits are also plagued by ambivalence and increasing disillusionment with my candy-coated past. On my last trip I discovered that the trailer home where my family had lived in the 1970s was, like many of the trailers that had once been installed by the military, thrown out in a dump at the south end of the island. There it sat rotting, infested with rats, its windows broken, graffiti sprayed on the walls. Like the rusty missile, it too was just a part of the ephemeral American suburban dreamscape. Like the Japanese sunken ships

35 Mark Gevisser, 2006, 'Inheritance', in Beautiful/Ugly: African and Diaspora Aesthetics, ed. Sarah Nuttall, pp. 204-223, Durham: Duke University Press, p. 223.

36 Monica LaBriola, 2006, 'Iien Ippān Doon: Celebrating survival in an "atypical Marshallese community"', unpublished MA thesis, University of Hawai'i at Mānoa, Honolulu. 
at the bottom of the lagoon and the Cold War paraphernalia strewn throughout the atoll, my childhood landscape, too, is swiftly turning into an archaeological site.

I take some solace in that thought, knowing that eventually the footprints of our trespasses may fade, but I worry that America will also forget what has happened here. Unlike the generations of Marshall Islander families who have lived in Kwajalein Atoll all along and remember these histories vividly, Americans come and go, and with them goes the institutional memory, the learning, the wisdom, and often the compassion for Marshallese neighbours and all they have endured.

And what of the rising waters of our warming earth that threaten to swallow all of these islands by the end of the twenty-first century? What will happen to the brave, generous and patient people of the Marshall Islands then?

Here in this special place, at home between the coral and concrete of Kwajalein, I remember that I have little choice but to surrender to the hugeness of it all. Everything continues to change, and silently and slowly the reef creeps outwards as it expands decade by decade. I feel deeply mournful, on the verge of tears; and simultaneously I feel overjoyed and awed by the largeness of this all. It is so much bigger than me, than any of us. I am grateful to know this reef, to listen to and tell its stories, and to continue this detour further.

\section{Acknowledgements}

I want to thank my parents, Walter and Christine, and my brother, Tim, for all of that they have taught me through our family's relationship to Kwajalein. I also want to express deep gratitude to my many teachers and mentors all throughout Oceania who continue to support me. In Japan I thank the Marshall Islands Bereaved Families Association for welcoming me to join them in honouring the atoll's war dead, especially Satake Esu, who passed away in 2010 after a long life devoted to peace. Finally, I thank my sixth grade teacher Miss Kasse, who urged me to save the essay I wrote for her class. 


\section{References}

Bell Laboratories. 1972. 'Kwajalein Orientation Guide.' Pamphlet.

Carucci, Laurence M. 1997. In Anxious Anticipation of Kuwajleen's Uneven Fruits: A Cultural History of the Significant Locations and Important Resources of Kuwajleen Atoll. Huntsville, AL: United States Army Space and Strategic Defense Command.

Chutaro, Suzanne. 2011. 'LUA signed after 8 years.' Marshall Islands Journal, 13 May.

Crapanzano, Vincent. 1985. Waiting: The Whites of South Africa. New York: Random House.

Dvorak, Greg. 2004. 'Remapping home: Touring the betweenness of Kwajalein.' MA thesis. University of Hawai'i at Mānoa, Honolulu, 2004.

- 2008. 'Seeds from afar, flowers from the reef, re-membering the coral and concrete of Kwajalein Atoll.' PhD thesis. The Australian National University, Canberra.

Gevisser, Mark. 2006. 'Inheritance.' In Beautiful/Ugly: African and Diaspora Aesthetics, ed. Sarah Nuttall, pp. 204-23. Durham: Duke University Press.

Hanlon, David L. 1998. Remaking Micronesia: Discourses over Development in a Pacific Territory, 1944-1982. Honolulu: University of Hawai'i Press.

Hirshberg, Lauren. 2012. 'Nuclear families: (Re)producing 1950s suburban America in the Marshall Islands.' Organization of American Historians Magazine of History 26(4): 39-43.

Horowitz, Adam. 1990. Home on the Range, Equatorial Films.

Johnson, Giff. 2013. Don't Ever Whisper: Darlene Keju-Pacific Health Pioneer, Champion for Nuclear Survivors: n.p.

LaBriola, Monica. 2006. 'Iien Ippān Doon: Celebrating survival in an "atypical Marshallese community".' Unpublished MA thesis, University of Hawai'i at Mānoa, Honolulu. 
Lal, Brij and Kate Fortune. 1999. The Pacific Islands: An Encyclopedia. Honolulu: University of Hawai'i Press.

Nuttall, Sarah. 2006. Beautiful/Ugly: African and Diaspora Aesthetics. Durham: Duke University Press.

Peattie, Mark. 1988. Nan'yō: The Rise and Fall of the Japanese in Micronesia, 1885-1945. Honolulu: University of Hawai'i Press.

Poyer, Lin, Suzanne Falgout and Laurence Marshall Carucci. 2001. The Typhoon of War: Micronesian Experiences of the Pacific War. Honolulu: University of Hawai'i Press.

Shuster, Donald R. 1982. 'State Shinto in Micronesia during Japanese rule, 1914-1945.' Pacific Studies 5(2): 20-43.

Teaiwa, Teresia. 1999. 'Reading Gauguin's Noa Noa with Epeli Hau' ofa's Kisses in the Nederends: Militourism, Feminism, and the Polynesian Body.' In Inside Out: Literature, Cultural Politics, and Identity in the New Pacific, ed. Vilsoni Hereniko and Rob Wilson, pp. 249-63. Lanham: Rowman \& Littlefield.

— 2001. 'L(o)osing the edge.' The Contemporary Pacific 13(2): 34357.

Tobin, Jack A. 1954. Ebeye Village: An Atypical Marshallese Community. Majuro, Marshall Islands. Photocopied report in University of Hawai'i Library Pacific Collection.

Tuan, Yi-Fu. 2003. Space and Place: The Perspective of Experience. Minneapolis: University of Minnesota Press.

United States Chief of Naval Operations (USCNO) (1943) Military Government Handbook OPNAV P22-1: Marshall Islands, Government Publication.

US Army Kwajalein Atoll (USAKA). 2001. 2001 Telephone Directory. US Army Kwajalein Atoll (USAKA). 2005. 'Kwajalein Battlefield Tour.' 
This text is taken from Touring Pacific Cultures, edited by Kalissa Alexeyeff and John Taylor, published 2016 by ANU Press, The Australian National University, Canberra, Australia. 